\title{
Universiteit
}

Leiden

The Netherlands

\section{The Sanskrit -yet-optative: A formation not yet recorded in Sanskrit grammars}

Kulikov, L.I.

\section{Citation}

Kulikov, L. I. (2006). The Sanskrit -yet-optative: A formation not yet recorded in Sanskrit grammars. Wiener Zeitschrift Für Die Kunde Südasiens, 50, 27-68. Retrieved from https://hdl.handle.net/1887/15231

Version: $\quad$ Not Applicable (or Unknown)

License: $\quad$ Leiden University Non-exclusive license

Downloaded from: $\quad$ https://hdl.handle.net/1887/15231

Note: To cite this publication please use the final published version (if applicable). 
INSTITUT FÜR KULTUR- UND GEISTESGESCHICHTE ASIENS

DER ÖSTERREICHISCHEN AKADEMIE DER WISSENSCHAFTEN

INSTITUT FÜR SÜDASIEN-, TIBET- UND BUDDHISMUSKUNDE DER UNIVERSITÄT WIEN

\section{WIENER ZEITSCHRIFT \\ FÜR DIE \\ KUNDE SÜDASIENS}

VIENNA JOURNAL OF SOUTH ASIAN STUDIES

Herausgegeben von

GERHARD OBERHAMMER

KARIN PREISENDANZ

CHLODWIG H. WERBA

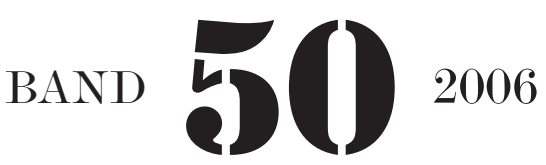

Verlag der

Österreichischen Akademie der Wissenschaften 


\title{
The Sanskrit -yet-Optative A Formation Not Yet Recorded in Sanskrit Grammars*
}

\author{
To my first guru of Sanskrit, \\ Prof. T.Ja. Elizarenkova
}

\section{Introductory Remarks}

"Kann kșipyet überhaupt eine richtige Form sein?"

(Böhtlingk 1897: 92)

In the individual verbal systems of a few Sanskrit verbs which can build only middle -ya-presents, or no -ya-presents at all, we find isolated forms in -yet, which at first glance cannot be anything but 3sg. active optatives of -ya-presents (class IV): kșipyet, -sisyet, sicyet, etc. Such forms are extremely rare and first appear in late Vedic and post-Vedic texts, and therefore are generally regarded as instances of late and erroneous diathesis replacement (middle $\rightarrow$ active). Accordingly, editions usually conjecture middle (passive) optatives instead $\left({ }^{+}\right.$-śisyeta, ${ }^{+}$sicyeta, etc.). One should note, however, that in most such cases there are no other (nonoptative) active forms based on a -ya-stem (**kșipyati, **śs şati, etc.); in other words, forms like kṣipyet and -śisyet prove to be isolated and their explanation as resulting from diathesis confusion seems unconvincing. This account is even less probable if the root in question has no

* I am much indebted to A. Lubotsky, Ch.H. Werba, F. Kortlandt, W. Knobl, T. Goudriaan, A. Griffiths, J. Houben, T. Oberlies, H. Tieken, N. Nicholas and Ya. Vasil'kov for their criticism and valuable comments on earlier drafts of the paper. I also would like to take this opportunity to express my thanks to the audience of the Second International Vedic Workshop (Kyoto, 1999), in particular to W. Knobl, T. Gotō, H. Falk and A. Parpola, for suggestions and critical remarks. I am also grateful to the participants of the Leiden Seminar on Indo-European linguistics ("donderdaglezing"), guided by R.S.P. Beekes, where an early version of this paper was discussed in 1998 - in particular, to R.S.P. Beekes, J. Houben, M. Oort, T. Zehnder and M. de Vaan. I acknowledge grant 275-70-009 (VENI-project) received from the Netherlands Organization for Scientific Research (NWO), and financial support from the Alexander von Humboldt-Stiftung. - The superscript symbol ${ }^{+}$shows that the following form is a conjecture; the double asterisk (**) indicates that the form does not occur in the texts and has probably never existed. ${ }^{\mathrm{m}}$ and ${ }^{\mathrm{p}}$ after the siglum of a Vedic text indicate that the passage in question appears in the mantra or prose portion of this text, respectively. 
-ya-presents (active or middle) or -ya-passives at all, as is the case with $k s i p$. All these facts require us to reconsider the paradigmatic status of such forms. To begin with, I will discuss a few such forms attested in Vedic prose.

\section{2. -yet-Optative: A Preliminary Hypothesis}

2.1. The form -śisyet occurs in the late GB (1.2.14: 47.11-12): na devayajanamātram purastāt paryavaśisyet. The same sentence also appears (with minor modifications) in the ȘB (2.10.12): tasya na purastād devayajanamātram atišisyāt. Bollée (1956: 63f.) translates:

East of it (the place of sacrifice) no space, wide enough for laying out another place of sacrifice, must be left. ${ }^{1}$

The form -sisyya $t^{2}$ is likely to be a root aorist optative, ${ }^{3}$ often also called "precative". The root śis has no root aorist indicative forms beside the optative -śisyāt, but, as Narten (1982: 128f. [= 1995: 255]) rightly points out, many roots build precatives, but lack indicatives and other nonoptative forms of the root aorist.

The parallelism of the two passages above, GB 1.2.14: 47.11-12 and ȘB 2.10.12, clearly indicates that -sisyet has the same value as the root aorist optative -śisyāt. In turn, the latter is probably functionally equivalent to the optatives based on the present stem with the nasal infix (also attested in late Vedic), which belong together with the transitive nasal present śinásți, śimșati Br. +, and thus can only be employed transitively, ${ }^{5}$ as in SंB 7.4.2.18:

sá yád amúm evòpadadhyát, némám apaśimsyàát, ksịipré hāsmáll lokád yájamānah préyāt "Now were he only to lay down that (golden man), and not to let this dviyagus (brick) remain, ${ }^{6}$ the Sacrificer surely would quickly pass away from this world" (Eggeling III/382).

Intuitively, -śisyet, -śisyāt and -śimssyát all belong together, but their exact relationship is unclear. Let us put -sisyet aside for a while and pass on

\footnotetext{
1 On this prescription, see Caland - Henry 1906: 7 with n. (9.3).

2 Mentioned by Eelsingh in the introduction to his edition of the ȘB (p. xxxiv) among "merkwaardige verbaalvormen".

3 Unless it is a scribal error for the present optative -śimsyāt (Ch.H. Werba, p.c.).

4 For this formation, see, for instance, Whitney 1884: 286ff. (= 1971: 294ff.); Bloch 1927; Burrow 1954; Hoffmann 1967; Narten 1982.

5 Cf. also Sāyaṇa's gloss -śeșayet.

${ }^{6}$ This part of the passage should probably be understood as "Würde er dann/aber nur den (Ziegel) dort anlegen, ohne den hier übrigzulassen ..." (Ch.H. Werba, letter of 26.06.2006).
} 
to another form in -yet, attested in the $\mathbf{S}_{\overline{\mathrm{A}}}$ (8.2): yad vā rte prānād retah sicyet, tat püyen, na sambhavet. Keith (1908: 51) translates: "If without breath seed were effused, it would decay, it would not be productive."

Both ed. ĀnSS and ed. Keith read sicyet, but the active -ya-present * sicyati does not exist in Vedic; we only find the -yá-passive sicyáte. Correspondingly, in his translation, Keith (1908: 51, n. 4) notices the irregularity of the form:7 ed. Bhim Dev and VWC-Br. II/1590a (with n. a) conjecture ${ }^{+}$sicyeta, apparently following the passive interpretation suggested by Keith.

As in the case of the parallel forms -sisyet and -sisyyat, sicyet can hardly mean anything different from the root aorist optative (precative) sicyāt, which occurs, for instance, in JUB 1.1.3.8 [ed. Oertel 1.3.8]: ... yatha kssirre kșìram a sicyāt ... "... as one would pour milk into milk ..." (Oertel).

The syntax of the context poses no difficulties. The form $\bar{a}$ sicyāt, derived from the fundamentally transitive verb sic "pour", is undoubtedly transitive, and sicyet must be such as well. Likewise, one may suppose that both the unclear -sissyet and its precative pendant -sissyat are employed transitively. This immediately raises a number of questions: are Bollée's and Keith's passive translations of -śisyāt (in ȘB 2.10.12) and sicyet (in $S \bar{A}$ 8.2) correct? Do we actually have sufficient reasons for taking the passages in question as (unambiguously) intransitive? If not, why have Keith and Bollée interpreted these constructions intransitively (passively)?

In fact, the aforequoted sentences in which the forms -sissyet, -sişyāt and sicyet occur are syntactically ambiguous - by virtue of the morphological ambiguity of the nouns retah and devayajanamatram (nominative/accusative); i.e. all three can be interpreted either intransitively ("no space ... should be left", etc.) or transitively ("he should leave no space", etc.). Apparently, both Keith and Bollée have associated - $y$ - in -śisyāt and sicyet with the present (passive) suffix -ya-. Since $y$ in the optative has nothing to do with the passive suffix -ya-, this analysis is certainly im-

7 "Sicyeta seems most probable, as sicyet is very irregular. Sicyāt, a precative form, is just possible, but not likely."

8 Narten (1964: 267, n. 845) conjectures an optative of the athematic nasal present ("wahrscheinlich Schreibfehler für sonstiges siñcyāt"); for this and other athematic forms of this nasal present, see Werba 1997: 254 ; for the athematic present optatives see also $\$ 6.2$ below. Oertel (p. 227, n. a.l.) hesitantly conjectures ${ }^{+} \bar{a}$ siñcet. Böhtlingk (apud Oertel 1895: coxliii [= 1994: I/27]), Caland (apud ed. Limaye - Vadekar, p. 380, n. i) and Sharma (see also p. 227 , n. a.l.) suggest ${ }^{+0}$ sicyeta. In my view, neither of these conjectures is in fact required. 
possible for the root aorist optative -sisyyat and should be likewise rejected for -sisyet and sicyet: as it seems, -y- in -yet is of the same nature as in $-y \bar{a} t$.

On the other hand, there are no good reasons to suppose that precatives (and "precative-like" forms) could not be employed transitively. Generally, root aorist optatives show the same syntactic pattern as other (primary) derivatives of the verb. In particular:

(i) root aorist optatives of fundamentally transitive verbs are employed transitively, ef. áa-bhriyāt (ŚB 1.5.1.20) "he should bring" (not * "he should be brought"), vadhyāt (Yajurveda) "he should slay", and other examples given by Narten (1964);

(ii) root aorist optatives of intransitive verbs are employed intransitively, cf. puṣyāsam "may I prosper", gamyás RV "he should come", etc. Thus, since transitive interpretations are syntactically possible and even preferable for -śisyet, -śisyāt and sicyet, the corresponding passages should be translated transitively, contra Keith (1908: 51) and Bollée (1956: 63f.), i.e.: "East of it ... he should leave no space ..." (for GB and SBB), and "If he were to pour seed without breath, it would decay ..." (for ŚĀ).

2.2. While the aforequoted passages containing sicyet and -sisyet are syntactically unclear, by virtue of the morphological ambiguity of the nouns involved (nominative/accusative), in the case of -dihyet, attested in the Bhārśs, the syntactic context leaves no choice. -dihyet can only be interpreted transitively (BhārŚS 11.17.10):

yadi bhidyeta, vidhum dadrānam iti saṃdhāya, yāni dṛ̣̣̂ārthe saṁśleșanāni, tair enam abhidihyed, yad anyan māsebhyo māmsāc ca, yad ṛte cid abhiśrișa iti "If [the Mahāvīra-vessel] would break, he should unite [its parts] with [the verse]: '[The grey-haired one has swallowed] the deadly hit [moon] which was walking [in the fight of many ones ... ${ }^{19}\left(\mathrm{RV}\right.$ 10.55.5 $=\mathrm{T}^{\mathrm{m}}{ }^{\mathrm{m}}$ 4.20.1, etc.) and besmear it with [things] which make [other things] cling together to [remain] (firmly) fixed (for some time), except beans and meat, with [the verse]: 'When [the one who unites] without ligature ...' $\left[\mathrm{TA} \bar{A}^{\mathrm{m}} \mathrm{ib.}\right.$.".

The parallel passage in ĀpŚS 15.17 .8 clearly shows that abhi-dihyet in the BhārŚS replaces the optative abhi-dihyāt:

yadi bhidyeta, vidhum dadrānam iti saṃdadhyāt, tato yāni dṛ̣̂̂ārthe samiśleșañāni syus, tair enam abhidihyāt ...

9 For this mantra, see Caland 1924: 76, n. 3 ad ĀpŚS 9.4.1; see also Tichy 1993: 15f. for the meaning of the hapax vidhú- ("tödlich getroffen"). 
The form -dihyāt may belong to the system of the root present (degdhi, etc.); however, in formal terms, this form can also be taken as an instance of the root aorist optative (precative), a formation which has become functionally (almost) equivalent to present optatives by the late Vedic period (see Narten 1982: 129 [= 1995: 256]).

Thus, the preliminary conclusions on the function and status of the forms -dihyet, -sisyet and sicyet (hereafter labelled -yet-optatives) can be recapitulated as follows:

(i) -dihyet, etc. do not belong with -ya-presents, nor with -yá-passives;

(ii) these forms are employed in the same usage as root aorist optatives (precatives) in -yát (sicyāt, etc.);

(iii) like the corresponding root aorist optatives, they can be employed transitively if the base verb is transitive.

\section{Attested Forms}

In what follows I will discuss forms in -yet which cannot be explained as optatives of active -ya-presents and thus may represent -yet-optatives.

$$
\text { kṣip "throw": kṣipyet }
$$

ChU 8.6.5 [kșipyet, ed. Böhtlingk ${ }^{+} k s ̣ ̄ y e t a$, Böhtlingk $(1876: 640)^{+} k s ̣ ̄ y e t$, VWC-Up. I/261b ${ }^{+} k$ șipet $]$

The form kșipyet, attested in an unclear ChU passage (8.6.5), has drawn the attention of Böhtlingk (see p. 27 above) and other interpreters. The passage runs:

atha yatraitad asmāc charī̄ād utkrāmaty, athaitair eva raśmibhir ūrdhvam $\bar{a}$ kramate. sa om iti ${ }^{+} v \bar{a} h{ }^{+} d v \bar{a} r a m{ }^{+} \bar{i} y a t e .{ }^{10}$ sa yāvat kșipyen manas, tāvad adityam gacchati.

Since neither (active) -ya-presents, nor -ya-passives can be derived in Vedic from $k s i_{p},{ }^{11}$ the form kșipyet appears even more irregular than

${ }^{10}$ Conjectures by K.F. Geldner; see Morgenroth 1981: 289ff. and Olivelle 1998: 569 (with bibliographical references) for a discussion of the initial part of the passage.

11 The passive of kșip appears in post-Vedic texts. In particular, we find kṣipyanti (with the abnormal active inflexion, see Bharadwaj 1982: 113; VWC-S $\bar{u}$. II/953, n. l conjectures the metrically impossible middle form ${ }^{+} k$ șipyante) in VișSmr. $43.42 \mathrm{~cd}$ : kvacit kṣipyanti bānaughair ' utkṛtyante tathā kvacit // "In some place they are shot (lit. thrown) with many arrows; in some place they are cut in pieces" (from a description of hell). Cf. also Epic Skt. part. act. aksşipyant- "being pulled, thrown" (Mbh. 1.16.15b); see Kulkarni 1943: 239 and Oberlies 2003: 265, 411. 
sicyet and -śisyet discussed above. Böhtlingk (1889) conjectures ${ }^{+} k s \bar{y} y e t a$, but the meaning "disappear" makes little sense in the context (in Böhtlingk's translation: "Während das Denkorgan verschwindet, gelangt man zur Sonne") $;{ }^{12}$ ef. ed. Senart 1930: 113, n. $3{ }^{13}$ In his edition Morgenroth (p. 506) accepts no emendation and interprets the form in question intransitively ("Der - wie schnell ein Gedanke ausschießt, so schnell gelangt er zur Sonne" [p. 368]), which is hardly possible for the fundamentally transitive verb ksip.

In my view, the normal (transitive) interpretation of ksip ("throw") better suits the sense of the passage $\left(V W C-U p\right.$. I/261b reads ${ }^{+} k$ sipet), which can be tentatively rendered as follows:

Now, when one exits from this body, then with those same rays one rises upwards. With the word "Om" this charioteer (?) drives to the gate. So long as he can direct [lit.: throw, send] ${ }^{14}$ his mind [thither], he comes to the sun.

Most likely, the form kșipyet cannot be grouped with -ya-presents, ${ }^{15}$ nor with -ya-passives. The interpretation of this form as an instance of -yetoptative renders conjectures suggested by Böhtlingk $\left({ }^{+} k s \underline{\imath} y e t,{ }^{+} k s \grave{i} y e t a\right)$ and $V W C-U p . \mathrm{I} / 261 \mathrm{~b}\left({ }^{+} k\right.$ ssipet $)$ unnecessary.

$$
\text { grh "seize, grasp": grhyet }
$$

Kauśs ${ }^{m} 82.21$ [grhyet, v.ll. grhhet, grhyot, duhyed]

The form grhyet occurs in an unidentified mantra quoted in the Kauśs 82.21:

\section{yad-yat kravyād grhyed yadi' kravyād̄̄ nānte 'paredyuh | divo nabhah śukram payo 'duhānā ișam ürjam pinvamānāh //}

Pādas ed are found (with some modifications) in Atharvaveda-Paippalādasamhitā 19.52.1-3 (see Griffiths 2004: 77); ${ }^{16}$ the source of Pādas ab is

12 The conjecture ${ }^{+} k s \bar{\imath} y e t$, earlier suggested by Böhtlingk (1876 [= Mélanges asiatiques, p. 640]), retains the active ending, but the present kșíya-te occurs with active inflexion only exceptionally (twice in TĀ 1.14.2).

13 “Je n'ose pas décider quelle est la lecture exacte : ksipyet n'est guère satisfaisant, et je crois moins encore à kṣ̂yeta qu'a conjecturé BöHTLINGK. Je traduis done un peu au hazard, d'après le sens que le contexte paraît suggérer avec beaucoup de vraisemblance."

14 Thus already Deussen (1897: 194): "... rasch wie man den Geist darauf richtet" - the interpretation which Böhtlingk (1897: 92) rejected. Cf. also Olivelle's (1998: 279) translation: "No sooner does he think of it than he reaches the sun."

15 Although the influence of the synonymous -ya-present asyati "throws" cannot be ruled out (W. Knobl, p.c.).

${ }^{16}$ Cf. also RV 9.74.4a: ātmanván nábho duhyate ghṛtám páyah "The animated cloud is milked [for] ghee [and] milk." 
unknown. Pāda $b$ is obscure and may require emendations, but the sense of Pâda a seems clear in the context of the funeral ritual to which this part of KauśS is devoted: "Whatever the flesh-eater (i.e. funeral fire) would grasp ...."

$$
\text { dih "(be)smear": -dihyet }
$$

BhārŚS 11.17.10 [abhi-dihyet] ( $\approx \overline{\mathrm{A} p S ́ S}$ 15.17.8 [abhi-dihyāt] $)$

The form -dihyet "he should besmear" has been discussed above (p. 30f.).

$$
d h y \bar{a} \text { "think of, reflect, meditate": dhyāyét }
$$

RVKh. 3.10².16 [dhyāyét, VWC-Sa. III/1744a ${ }^{+}$dhyáyet] $(\approx \mathrm{BD} 6.145)$

The form dhyāyét (transmitted with a final accentuation, which is impossible for the class IV present dhyáya- ${ }^{l i}$ attested for this root) occurs in RVKh. $3.10^{2} .16$; the verse is also quoted (with minor modifications) in BD 6.145:

pāvamānồm piț̣̂n ${ }^{+}$devân ' dhyāyéd +'yáś ca ${ }^{+}$sárasvatīm | +piltṛms + tásyópa tiș̣heta ' kșìrám sarpír mádhūdakám //

"And who meditates on the Pāvamāni (stanza), on the fathers, on the gods, and on Sarasvatī, his fathers (only) milk, ghee, honey, (and) water may approach."

The verse is based on the rgvedic stanza 9.67.32, which has undergone essential changes, however:

pāvamānốr yó adhyét $t_{i}$ ' ṛsibhih sámbhṛtam rásam /

tásmai sárasvatī duhe ' kṣ̂̀rám sarpír mádhūdakám //

"Who knows by heart the Pāvamānī [verses], the sap brought together by the R̦̣is, Sarasvatī gives him milk, ghee, honey, water."

dhyāyéd yaś seems to originate in rgvedic yó adhyéti, and the awkward form $d h y \bar{a} y e ́ t$ undoubtedly results from misunderstanding rgvedic adhyé$t i$, to which it may owe its unusual accentuation. Although the passage contains a few words with clearly corrupt accentuation (yaś ca, sarás-

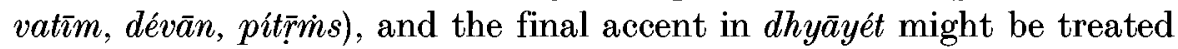
likewise, it cannot be ruled out that introducing this accent placement could have been supported by the morphological model of the -yet-optative, which might inherit its final accentuation from precatives in -yát. Under this analysis, the accent emendation $\left({ }^{+} d h y \bar{a} y e t\right)^{17}$ becomes unnecessary.

$17 V W C-S a$. III/1744a and n. g (with question mark). 
This analysis is indirectly confirmed by the parallel of the root aorist optative in -yāt (dhyāa $\bar{a} t$ "he should think"), attested in Vedic prose - for instance, at KB 8.7.6 and 9.5.19.

$$
\text { pad "fall": }{ }^{+} \text {-padyet }
$$

$\bar{A} r s ̣ U$ 7,14 [vi ... ${ }^{+}$padyet (corr. Tsuji 1957: 21 f.); ed. Belvalkar, ed. Shastri ${ }^{\circ}$ padyat; VWC-Up. II $/ 773 \mathrm{a}{ }^{+o}$ padyan $]$

A -yet-optative may underlie the unclear form -padyat attested in the post-Vedic Ārșeya-Upanișad (ed. Belvalkar, p. 7, 13-14): ... vīva padyad artim rechet "... he would perish, he would run into misfortune."

Instead of the morphologically impossible -padyat, ${ }^{18}$ VWC-Up. II/773a hesitantly conjectures act. part. ${ }^{+}$-padyan. An optative form is more appropriate in the context, however (cf. the adjacent rcchet), and, correspondingly, Tsuji's (1957: 21f.) emendation ${ }^{+}$padyet seems more likely.

\section{bhañj "break": -bhajyet}

MānGS 2.15.6 [prabhajyet, ed. Sastri obhajet, Falk (1994: 323) *obhujet] The -ya-present bhajya-te (the intransitive counterpart of the nasal transitive present bhanákti) first appears in post-rgvedic mantras (AV, RVKh.). By virtue of its semantic, syntactic and paradigmatic features, it seems to belong with the non-passive middle -ya-presents with fluctuating accentuation (cf. esp. bhidyá-te and chidyá-te; see Kulikov 1998 and 2001: 361, 533, 543). The earliest active occurrence is the post-Vedic optative -bhajyet attested in the MānGS (2.15.6):

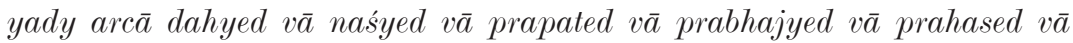
pracaled $v \bar{a} . .$. "If the image of a god burns, or disappears, or falls down, or breaks, ${ }^{19}$ or laughs or trembles ..." (a list of omens).

Instead of -bhajyet (as in ed. Knauer), Sastri reads ${ }^{\circ}$ bhajet (thus reckoning this form to the root bhaj "share, distribute"), but the meaning of pra-bhaj ("execute, accomplish") makes no sense in the context. Falk (1994: 323, with $\mathrm{n}$. 31) rejects both readings and hesitantly conjectures *obhujet ("[falls ein Verehrungsobjekt ...] sich beugt ..."), but his emendation seems too drastic; note also that the rare compound pra-bhuj occurs in the Sūtras only in the absolutive (prabhujya). In my view, the

18 Taken as an augmentless imperfect by Renou (1957: 129); see Tsuji's (1957: 21) objections.

19 Rather than "is crushed" (passive) in Dresden's (1941: 165) translation. 
meaning of prá-bhañj (well-attested from the RV onwards) perfectly suits the context and the reading adopted in ed. Knauer is most likely. Although the active inflexion of the form prabhajyet can readily be explained as emerging under the influence of the adjacent active optatives (cf. the similar case of manyet discussed below), it cannot be ruled out that -bhajyed represents a -yet-optative; note especially the lack of other (non-optative) active forms built on the stem -bhajya- in the Sutras.

$$
\text { bhrj(j) "roast": bhrj(j)yéyur }
$$

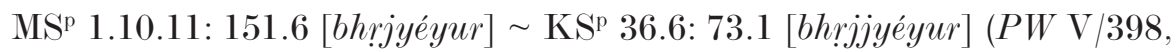
Hoffmann 1985: 173, Werba 1997: $213^{+}$bhrjjéyur)

The plural optative form bhrj(j)yéyur is attested in two Sampitās of the Black Yajurveda (MS 1.10.11: $151.6 \sim$ KS 36.6: 73.1-2):

yád bhrjyéyur [KS bhrjjyéyur], ánaveștam ámhah syāt "If they would roast [the grain], ámhas (narrowness) would not be removed by sacrificing."

The form in question cannot be the optative of an active -ya-present ${ }^{20}$ (otherwise unattested) because of the suffix accentuation. Already Roth

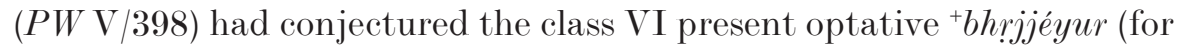
the Kăthaka occurrence). Renou (1940: 7) noticed the secondary character of $-y$ - in this form; Hoffmann (1985: 173 [= 1992: 814]) explained *bhrjyáti as a hypersanskritized substitute for the class VI present bhrjjáti (see also Werba 1997: 213).

Although the class VI analysis of this form is possible, it cannot be ruled out that bhrj(j)yéyur is the plural pendant of the -yet-optative *bhrj(j)yét - which renders the emendation ${ }^{+}$bhrjjéyur unnecessary.

$$
m \text { r "die": mriyet }
$$

AmṛtU 38 [mriyet (Weber 1865: 37f., ed. Āpțe, ed. Mahadeva Sastri $=$ ed. Acarya 39)]

The form mriyet occurs in the concluding verse of the late AmṛtanādaUpanișad:

yatra-yatra mriyed vāpi' na sa bhūyo 'bhijāyate // (AmṛtU 38cd = [ed. Acarya] 39cd) "Wherever [this adept] would die, he is not born again" (see Varenne 1971: 121f. and 156, n. 32).

20 Thus Bartholomae 1925: 34 (followed by KEWA II/520 and EWAia II/278), according to whom bhrjj can be traced to bhrj-y- (ef. Av. -bərajiia-). 
The irregular character of the form was noticed by Weber (1865: 38). ${ }^{21}$

$$
m r j \text { "wipe off, destroy": -mrjyet }
$$

GB 1.4.13: 104.13 [nir-mrjyet, ed. Gaastra ${ }^{+}$nir-mrityet] ( $\approx$ SBM 12.1.3.23 [vi-mrityét $]$ )

The form nir-mrjyet occurs in the GB, probably replacing the original -yet-optative of mrit, vi-mrityét (attested in the parallel passage of the SB). For a detailed discussion of the relevant passage, see below, s.v. mrit (p. 37, n. 27).

mrit (/mlit, mrt $)^{22}$ "decay, rot; dissolve": -mri/rtyét, -mrityeyur ${ }^{23}$ SBM 3.2.1.31 [ $\left.{ }^{+} a p a ~ . . . m r i t y e t\right] \approx S \operatorname{SBK}$ 4.2.1.22 [ápa-mrtyet (v.ll. ápammṛ́tye ${ }^{\circ}$, áyammṛtye $e^{\circ}$ ápamịtye $\left.{ }^{\circ}\right)$; SBM 12.1.3.23 [vi-mrityét, ví-mrityeyur] $(\approx \mathrm{GB}$ 1.4.13: 104.13f. nir-mrjyet, nir-mrjyeran, ed. Gaastra ${ }^{+}$nir-mrtyet, ${ }^{+}$nir-

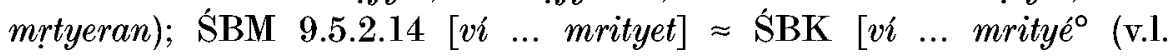
$\left.\left.{ }^{\circ} m r t y e^{\circ}\right)\right]^{24}$

The isolated optative forms mrityét and -mrityeyur, which do not occur outside $\mathrm{SB},{ }^{25}$ are treated in $P W \mathrm{~V} / 932$ as forms of the intransitive active -ya-present *mritya- ("zerfallen, sich auflösen"). After Böhtlingk and Roth's dictionary $(P W)$, this analysis has been followed by all grammars and dictionaries ${ }^{26}$ and adopted in Indo-Iranian and Indo-European scholarship; cf. Mayrhofer, KEWA II/695f.; EWAia II/387 ("zerfallen, sich auflösen"). In Avestan studies this intransitive -ya-present is taken as the counterpart of Avestan friછiieiti; cf. Geldner 1896: 52; Kellens 1984: 120f. ("se décomposer"); Werba 1997: 220 ("verfaulen/rotten, sich auflösen").

The semantics and syntax of mrityét and mrityeyur pose no difficulties in the following two passages:

21 "mriyet ist eine ungewöhnliche Form, Passivum mit der Endung des Activs."

22 For the relationship between the root variants mrit and $m r t$, see, in particular, Oertel 1926: 240ff.; 1927: 106 [= 1994: I/565].

${ }^{23}$ I have greatly benefited from discussing the interpretation of the relevant passages with W. Knobl and Ch.H. Werba. Of course all responsibility for possible mistakes and misinterpretations is mine.

${ }_{24}$ See ed. Caland II/470; for the numeration, see ed. Caland I/117 (ŚBM 9.5.2 $\approx$ ŚBK 11.7.2).

${ }_{25}$ For occurrences in GB 1.4.13 (which is likely to be based on SB 12.1.3.23; see GB, ed. Gaastra, Einleitung, p. 21), see below, n. 27.

26 Thus Whitney 1885: 127 (though with a question mark); Delbrück 1888: 340; 1897: 33 (with the tentative accent emendation ${ }^{+}$mrityati); Uhlenbeck 1899: 233; Monier-Williams 837 ("decay, be dissolved"); Werba 1997: 220. 
átha yá u hainam ápy etárhi táthopeyúr, yáthāmapātrám udaká ásikte vimrityéd, evám haivá té vímrityeyuh (ŚB 12.1.3.23 [ح GB 1.4.13: 104.12-14 ya enam adya tathopeyur, yathāmapātram udaka āsikte nirmṛyed, evam yajamānā nirmrjyeran $]^{27}$ ) "[B] ut if nowadays any (sattrins) were to perform it [sc. the rite] on this wise, they assuredly would crumble awa ${ }^{28}$ even as a jar of unbaked clay would crumble away if water were poured into it." (Eggeling V/144). ${ }^{29}$

ná táthā kuryād, yáthā śusṣam sthānúm udakénābhiṣiñcét tāḍ̣k tát, púyed vā vái sá ví vā mrityet (ŚB 9.5.2.14). "He should not act that way, [for] it would be as if one were to besprinkle with water a withered trunk; it would rot or fall to pieces (dissolve?)."

More problematic is the third occurrence of this formation, at ŚB 3.2. 1.31:

yó vái gárbhasya kāṣthéna vā nakhéna vā kạ̣dūyéd ápāsyan mrityet "and were any one to scratch an embryo either with a chip of wood or his nail, thereby expelling it, it would die" (Eggeling II/33).

This translation suggests quite an odd syntax in the complex sentence ("who scratches ..., $[\underline{\mathrm{it}}=$ the embryo (?)] dies"). The postposition of "assyan, interpreted by Eggeling as participle of as "throw" in spite of the lack of accent on the verbal form, ${ }^{30}$ is also unusual.

${ }^{27}$ Ed. Gaastra conjectures in both cases ${ }^{+0}$ mrity $^{\circ}\left({ }^{+}\right.$nirmrityet, ${ }^{+}$nirmrityeran $)$for the reading ${ }^{\circ}$ mrjy ${ }^{\circ}$ (nirmrjyet, nirmrjyeran) attested in mss. and adopted in ed. Mitra. The reading attested in the GB must be secondary, based on the replacement of the forms of the rare root $*^{\circ}$ mrit $^{\circ}$ with those of the much more common $m r j$ (see Oertel 1926: 241 and 1927: 106 [= 1994: I/565]; Patyal 1973: 255), which is most frequent with the preverb nir-, meaning "wipe off, destroy" (Ch.H. Werba's p.c., letter of 16.07.2006). Such replacement could trigger the concomitant adjustment in the morphology and syntax of the passage. Specifically, while nirmrjyet may represent a -yet-optative of nir-mrj ("one would destroy (it)"), nirmrjyeran cannot be anything but the 3pl. pass. opt. form of the same compound, replacing the original 3pl. form of the -yet-optative of vimrityeyur. The fundamentally transitive syntax of (nir-) mrj may be responsible for the passive syntax of the resulting construction, replacing the original non-passive intransitive sentence. Accordingly, the variant of the SB passage attested in the GB can be tentatively translated as follows (Ch.H. Werba, ibid.): "Wenn man heute an ihn so heranginge, würden, wie [wenn man] ein rohes (Ton-)Gefäß mit Wasser begösse und es so vertilgte, so die Opferherrn vertilgt werden" (emphasis is mine - LK).

28 The compound with the preverb vi- should rather be translated as "crumble asunder, fall to pieces".

29 Likewise, Delbrück (1888: 340): "diejenigen aber, welche auch jetzt noch so zu ihm kommen sollten, würden zerfallen, als ob ein rohes Gefäss zerfiele, nachdem Wasser hineingegossen ist"; Oertel 1926: 240; Minard (1956: 178 [441]): "ceux qui, aujourd'hui encore, accompliraient ainsi ce (rite), comme un vase (d'argile) crue se déliterait si l'on (y) versait de l'eau, tout ainsi se déliteraient-ils."

30 In order to explain away this abnormal accentuation, Eggeling II/33, n. 2 suggests a plausible conjecture, 3sg. opt. "ápāsyet "he would force it out". 
A different syntactic analysis of mrityet has been suggested for ŚB 3.2.1.31 by Caland (as well as by Lindner, in his unpublished translation of the SB, also quoted by Caland) in his "Kritisch-exegetische Bemerkungen zu den Brāhmanas" (1912: 116 [= 1990: 204]). Caland's interpretation is based on the Kānva recension (4.2.1.22): ... kandūyéd ápa mrtyed ${ }^{31}$ asya ... (cf. ŚBK, ed. W. Caland, Introduction, p. 42 [§9c]).

Caland conjectured ${ }^{+} a ́ p \bar{a} s y a m r i t y e t$ for ápāsyan mrityet in the Mādhyandina recension and translates both versions as "so würde er ihm schaden (?)" or "die Haut desselben abschaben (?)".

A more attractive interpretation of this passage has been suggested to me by W. Knobl (p.c., letters of 27.08.2001 and 20.01.2005), who adopts Caland's conjecture ${ }^{+}$ápassya mrityet for both recensions of the SB and translates the whole passage as follows: "Wer etwa das Kind im Mutterleib mit einem Stück Holz oder mit dem Nagel kratzen würde, $\underline{\text { dem }}$ (!) würde es abgehen (d.h. als Frühgeburt missraten)." Thus, the compound ápa-mrit is taken as synonymous with srīv or ápa-pad "be aborted". Still, the syntactic structure of the passage remains not quite clear.

Finally, Ch.H. Werba (p.c., letter of 16.07.2006) suggested a plausible correction to the interpretation of the compound ápa-mrit, rendering it in the sense of German ab-faulen, i.e. "solange verfaulen/verrotten, bis der Embryo dann auch abgeht". Accepting the above-mentioned conjecture ${ }^{+} a ́ p \bar{a} s y a$ mrityet, he offers the following interpretation of the passage in question (which, incidentally, accounts for the genitive gárbhasya in the subordinate clause): "Würde man an der Eihaut des Embryo schaben oder kratzen und diese damit beschädigen, so würde sich einem diese Eihaut und damit der Embryo selbst auflösen und schließlich als Totgeburt abgehen ...."

Another formation which belongs to this verb (made from the $l$-variant of the root, $\mathrm{mlit}$ ) is the absolutive derived from the causative stem mletaya-, a-sammletya "without chewing [it]", attested in the Śrautasūtras (ĀpŚS 3.19.7 = VaikhŚS 7.1: 69.6, etc.).

The final accentuation of vimrityét in ŚB can be accounted for under the assumption that mrityét does not belong with the -ya-presents, but represents a separate morphological formation, parallel with and functionally equivalent to the root aorist optative (precative) in -yát and adop-

31 V.ll. ápammịtyet, áyammịtyet, ápamịtyet. Note that the ŚBK has preserved the root variant mrt. 
ting its final accent. The form -mrityeyur can be identified as the plural counterpart of mrityét.

$$
\text { ram "stop": -ramyet }
$$

BaudhŚS 24.7: 190.15 [vi-ramyet (ed. Caland, ed. Kashikar), v.ll. ' ramyeta, ${ }^{\circ}$ rasyeta]

The optative vi-ramyet occurs in BaudhŚS 24.7: 190.14-15: na karmano hetor mantro viramyet "The mantra should not stop for the sake of the rite." 32

Caland (1903: 42) noticed this form as "merkwürdig", mentioning that Veṅkateśvara's commentary glosses it as na viramet. Since active -yapresents are not derived from this root, ${ }^{33}$ the form in question is likely to represent a -yet-optative.

$$
\text { vid "know": vidyet }
$$

JābU 4: 66.6 [vidyet, v.ll. vidyāt, vindet, veda, ed. Schrader vindet]

The form vidyet appears among variant readings in the late JabbalaUpaniṣad:

yady agnim na vinded apsu juhuyāt. āpo vai sarvā devatāh. sarvābhyo devatābhyo juhomi svāheti hutvoddhṛtya prāśn̄ìāt sājyam havir anāmayam. mokșamantras traȳ. evam vidyet (JābU 4: 66.3-6). "If he cannot obtain fire, he should offer [the oblation] in the waters. All the deities verily are the waters. He should offer the oblation with the words 'I offer to all the deities, hail!', take [some from it] and eat that salubrious oblation mixed with clarified butter. The triple [Veda] is the mantra of liberation. Thus one should know" (cf. Olivelle 1992: 144).

Schrader adopts the reading vindet (attested in a number of mss.), but in Vedic the nasal present can only be derived from the homonymous root ${ }^{1}$ vid "find, obtain" (vindáti, etc.), not from ${ }^{2}$ vid "know". Although in post-Vedic texts (in particular, in Epic Skt.), when both roots become confused, the nasal present of ${ }^{2}$ vid "know" does occur, in our passage the form vindet seems to have been triggered by the present optative vinde $[t]$ "he can(not) obtain" at the beginning of the passage. Among the attested readings only vidyāt (precative) can belong to ${ }^{2} v i d$ "know" as a correct form, and vidyet may have arisen as its secondary variant

32 For this prescription, see Gonda 1977: 510.

33 Middle - ya-presents are rare, late and secondary, attested in the imperative $a b h i$ ramyatām (KaușGS 3.14.16 ŚGS 4.2.6 GautPS 2.6.13, for which see Caland 1895: 108, 112 [= 1990: 18, 22]; but Hultzsch's ms. reads ' ramate; see Appendix to Caland's ed. of the GautPS, p. 132); the parallel passage VișSmr. 73.26 reads abhi-ramantu. 
(on the relationship between precatives and optatives in -yet-, see below $\$ 5-6)$.

$$
\text { śams "recite": -śasyet }
$$

ŚŚS 17.9.6 [sam-śasyet]

The transitive -yet-optative -śasyet is attested in ŚŚS 17.9.6: ubhe sūkte pacchah samśasyet "He should recite together both hymns by versequarters."

śiṣ "leave, remain": śiṣyet

GB 1.2.14: 47.12 [(tr.) paryava-śișyet] (= VaitS 11.5); VaikhŚS 21.4: 325.2 [(intr.) śisyet]; BhārŚS 7.3 .9 [(intr.) uc-chisyet, VWC-Sū. I/628b ${ }^{+0}$ yeta]

In contrast to the transitive -yet-optative paryava-śisyet "he should [not] leave" (GB 1.2.14: 47.12), discussed above (p. 28ff.), both occurrences of sişyet in the Śrautasūtras are intransitive:

yat prokṣañinām ucchisyet ... (Bhārśs 7.3.9) "What of the sprinklingwaters remains ..."; yadi ... alpasomah śisyet ... (VaikhŚs 21.4: 325.1-2) "If ... a little Soma remains ...."

For BhārŚŚ 7.3 .9 ucchișyet, VWC-S̄u. I/628b (with n. h) conjectures ${ }^{+o}$ yeta (with a question mark); likewise, in VaikhŚS, ed. Caland (Preface, p. xviii), sisyet is considered a secondary replacement of the regular middle optative śisyeta. Under the assumption that śisyet is a -yet-optative, both conjectures, albeit quite plausible per se, are unnecessary. The syntactic variability (transitive/intransitive) can be explained by the fact that both transitive and intransitive usages are equally basic for this verb (ef. śimsáti, śináști "leaves" and śişyate/śișyáte "is left, remains" ${ }^{34}$ ), which makes both transitive and intransitive usages of -yetoptatives possible.

$$
\text { sañj (/sajj) "hang, attach": }{ }^{(+)} \text {-sajjet }
$$

MānŚS 1.1.3.6 [ ${ }^{(+)}$ava-sajjet $\left(\leftarrow{ }^{*}{ }^{\circ}\right.$ sajy $\left.{ }^{\circ}[?]\right)$, v.l., ed. van Gelder ava-srjjet] A -yet-optative may underlie the form -sajjet attested as a v.l. in Mānśs 1.1.3.6, which van Gelder reads as follows: darbhamayam pavitram trigunarajju śākhāyām anulomam avaș̣jed, granthim akurvan. The meaning of $\operatorname{srj}$ ("release, set free") does not suit the context, however, and, in fact, van Gelder has translated the passage differently: "On (the top of) the

\footnotetext{
34 On the accent fluctuation in this present, see Kulikov 1998.
} 
branch he shall fix three Darbha blades as a strainer, their tips on the top of the branch; he shall not make a knot."

The original reading (on which van Gelder's interpretation is apparently based) could have been preserved in one of the ms. sources used by Knauer, abbreviated in the critical apparatus as Kc (fragments from the Mānava-, Kāthaka- and other Sūtras collected by A. Weber from the commentary on the KātyŚS). Ke reads the form in question as avasajjet, which can only be derived from the root sañj (/sajj). This reading is hesitantly adopted by Caland (1902: 124 [= 1990: 604] $)^{35}$ and mentioned by van Gelder (in crit. app.), who surmises a sporadic gemination ("perhaps "vasaje is right"). In my view, the gemination can be readily explained as the Prakrit-like reflex of the cluster -jy-, attested, in particular, in pres. sajjate ( $\leftarrow$ pass. sajyáte), ${ }^{36}$ which occurs, for instance, in ŚB 14.6.9.28 (v.l.), ${ }^{37}$ NidānaS 9.8: 163.12, 18, 25, in some late Upaniṣads, Epic and Class. Skt. Although sajja- does occur with the active inflexion (from the Śrautasūtras onwards), and we cannot rule out that the form in question is the optative of the secondary present sajjati, an analysis in terms of -yet-optatives seems very likely; note that a non-optative form of this present occurs in the Śrautasūtras only once (VaikhŚS 18.6: $256.16 \bar{a}$-sajjati).

$$
\text { sic "pour": sicyet }
$$

\section{ŚĀ 8.2 [sicyet, ed. Bhim Dev, VWC-Br. II/1590a ${ }^{+}$sicyeta]}

The form sicyet "[if] one were to pour" has been discussed above, p. 29f.

$$
s \bar{u} \text { "beget": sūyet }
$$

AVPar. 71.7.1 [sūyet $]$

The form sūyet occurs in the Pariśisțas of the Atharvaveda:

yonivyatikaram yatra' kuryur evamvidham striyah / gaur vā sūyet tathānyāni' tatra räjyam vinaśyati // (AVPar. 71.7.1) "Where females produce such [freaks] as a result of confusion of wombs, or a cow gives birth to other [kinds of offspring], there the kingdom perishes." 38

${ }_{35}$ “... ist vielleicht die Lesart von Kc richtig, da dem avasajjet oder avasajet bei Baudh. pravestayati entspricht."

36 Cf. Gotō 1980: 27 and 35, n. 47; 1987: 322, n. 779; Kümmel 1996: 119 with n. 232; Werba 1997: 250; Kulikov 2001: 208-210.

37 Mss. read sájyate and sájjate; see ed. Weber, crit. app.

38 I am grateful to Ch.H. Werba for valuable clarifications on the meaning of this passage. 
The transitive -ya-present siuya-te "beget" (competing with the old root present súte $\mathrm{RV}+$ ) first appears in the post-Vedic period, in particular, in VișSmr. and AVPar.; ${ }^{39}$ cf. pra-sūyante at AVPar. 71.7.4, i.e. just a few verses after the aforequoted passage, süyate at AVPar. 71.11.1, and, especially, the middle optative prasüyeta employed in a similar context (gaur aśvam ... prasūyeta) at AVPar. 71.5.2. However, forms with active inflexion do not occur until Epic Skt.; Gotō (1991: 698) mentions only one attestation in Mbh. Although active forms frequently substitute for the regular middles in AVPar. (dīpyati for dīpyate, vāśyati for vāśyate), the lack of non-optative forms (**sūyati, etc.) makes the analysis of suyet as a -yet-optative very likely. It is worth mentioning that the AVPar. quite often employs optative forms in indicative usages, in particular, in indefinite relative clauses (see Modak 1993: 467); the abovequoted passage (mentioned by Modak, ibid.) is a typical example of such a usage.

snā "bathe, swim": snāyet, -snāyeyur

GB 1.5.2: 114.4, 6, 9, 12, 15 [pra-snāyeyur] $(\approx$ ŚB 12.2.1.1ff. [pra-sná$\left.n t i]^{40}\right)$; Mānavānugrāhikasūtra 23 [snāyet]

The plural optative form -snāyeyur occurs a few times (in the same syntactic context) in a GB passage:

gādham pratisțthā caturvimiśam ahar yathopakaksadaghnam vā kaṇthadaghnam vā yato viśramya prasnāyeyus, tādṛk tat $(\mathrm{GB}$ 1.5.2: 114.3f. $=5 \mathrm{f} .=8 \mathrm{f}$. $=11 \mathrm{f} .=14 \mathrm{f} .[\approx$ ŚB 12.2.1.2=4 yáthopapakșadaghnám vā kanthadaghnám vā yáto viśrámya prasnánti]) "The Caturvimía-day is a ford, a foothold. As if having rested [where the water] reaches (only) to the arm-pits or to the neck, one would swim forth from there, so it is."

Werba (1997: 329) records this form as the optative of the secondary -ya-present. Note, however, that, apart from one isolated middle form in a late mantra (MānŚS $S^{m}$ 8.20.8 snāyasva; see Kulikov 2001: 593), the -yapresent snāya-te only occurs in post-Vedic texts (see Werba, ibid., and, for attestations in Epic Sanskrit, Oberlies 2003: 194, 538). Rather, the form -snāyeyur instantiates a -yet-optative (pl.), parallel to the root present optative $s n \bar{a} y \bar{a} t$ (which might equally be a precative), attested, in particular, in GB 1.2.2: 34.3 and TĀ 1.26.7.

39 See Gotō 1991: 698.

40 The form pra-snāyúr attested in ŚB 12.2.1.1 corresponds to the optative pratareyur at GB 1.5.2: 114.2. 
The corresponding singular form occurs in Mānavānugrāhikasūtra 23 (quoted from Caland 1896: 83, n. 304), probably emerging under the influence of the adjacent active optatives:

śucivāsā notsaveșu gachen, nākāle snāyen, na hrşyet "[His wife], clothed in pure garments, should not go to festivals, should not bathe at the wrong time, should not rejoice."

\section{The Morphology, Syntax and Semantics of -yet-Optatives}

\section{A Recapitulation}

\subsection{Morphology}

The -yet-optative can now be safely posited as a separate morphological type, albeit late, marginal and rare. Correspondingly, the forms in -yet / -yeyur discussed above need not be emended.

The rules of derivation are essentially the same as for the regular root aorist optatives ("precatives"), apart from é instead of $\bar{a}$; i.e. -yét is attached to the zero grade root. The plural form in -yéyur is probably made by analogy with class IV present optatives. Thus, unaccented -yet-optatives are formally indistinguishable from 3rd person active optatives derived from -ya-present stems; in other words, a form in -yet can be identified for certain as a -yet-optative only in the cases where there are no active -ya-presents derived from the root in question.

Unlike root aorist optatives in -yāt, etc., the -yet-optative seems never to have developed a full paradigm, thus being similar to other isolated formations with defective paradigms, such as passive $-i$-aorist. I was unable to find forms beside 3sg. and 3pl. (for instance, a hypothetical $2 \mathrm{sg}$. form might be *kșipyés).

\subsection{Syntax and Transitivity}

-yet-optatives follow the syntactic pattern which is typical of the base verb. It should be emphasized once again that $y$ in -yet-optatives has nothing to do with $y$ in (intransitive) -ya-presents and/or -yá-passives, so that transitive verbs do not become intransitive in -yet-optatives. That is, if a verb is (fundamentally) transitive, its -yet-optative is employed transitively: ksipyet "he should throw", bhrj(j)yéyur "they should roast", -śasyet "one should recite", sicyet "one should pour", etc. On the contrary, if a verb is intransitive, its -yet-optatives are employed intransitively; cf. mriyet "he should die", and -ramyet "he should stop". The 
-yet-optative sisyet can be employed both transitively ("one should leave") and intransitively ("it would remain"), since both syntactic patterns are well attested for the verb sis s.

In addition, one should note that the majority (approximately twothirds) of -yet-optatives are transitive. This ratio does not necessarily represent a syntactic feature of -yet-optatives, ${ }^{41}$ but it may have influenced the choice of syntactic pattern in those cases where both transitive and intransitive usages were possible; see below, p. 52, $\S 7.1$ on the post-Vedic optative trudyeyur. Incidentally, an unusual syntax (particularly, higher transitivity) may be the only criterion distinguishing unaccented -yet-optatives from the regular present optatives in the cases where active -ya-presents can be derived from a given root. ${ }^{42}$

\subsection{Semantics}

Evidence is too scant to assume any specific meaning for -yet-optatives, in contrast with the corresponding (far more common) regular present optatives. It seems that this formation is employed in the same usage as precatives in $-y \bar{a} t$ - which, in turn, have become functionally (almost) equivalent to present optatives by the late Vedic period (Narten 1982: 129 [= 1995: 256]) and, eventually, almost disappear by that time (Hoffmann 1970: 66f. [= 1976: 517f.], n. 2). ${ }^{43}$

\section{Paradigmatic Features and the Origin OF THE -YET-OPTATIVE}

In order to trace back possible sources of the -yet-optative, I give a synopsis of all forms in -yet / -yeyur, together with the corresponding

41 This disproportion can be partly accounted for by the fact that a good many fundamentally intransitive verbs build active -ya-presents, the optatives of which are indistinguishable from -yet-optatives in unaccentuated texts.

42 Such may be the case with the optative form krudhyet, constructed with the accusative in VaikhŚS 12.11: 141.4 (anyam na krudhyet; see VaikhŚS, ed. Caland, Preface, p. xix), in contrast to the forms of the -ya-present krudhya- ${ }^{t i}$, typically constructed with the dative.

43 Hoffmann's claim that the precative totally disappears in late Vedic seems too categorical. However, some rare forms (such as the aforementioned -śișyāt ȘB 2.10.12 and -sicyāt JUB 1.1.3.8 [ed. Oertel 1.3.8]) still occur in late texts; see also the list in Renou 1940: 13f., n. 1 and ef. the examples from Epic Sanskrit in §7.1. 
present formations attested for the same root, and, for comparison, a selection of root aorist optatives (precatives):

\section{-yet-optatives}

\begin{tabular}{|c|c|c|}
\hline $\begin{array}{c}k s \underline{i p} \\
g r(b) h\end{array}$ & $\begin{array}{l}\text { kssipyet } \\
\text { grhyet }\end{array}$ & \\
\hline dih & -dihyet & \\
\hline$d h y \bar{a}$ & dhyāyét & \\
\hline pad & ${ }^{+}$-padyet & \\
\hline bhañj & -bhajyet & \\
\hline $\operatorname{bhrj}(j)$ & & bhṛ(j)yéyur \\
\hline$m r$ & mriyet & \\
\hline$m r j$ & mrjyet & \\
\hline mrit & -mrityét & -mrityeyur \\
\hline ram & -ramyet & \\
\hline vid & vidyet & \\
\hline śams & -śasyet & \\
\hline sís & -sisṣyet & \\
\hline$s a \tilde{n} j$ & ${ }^{(+)}$-sajjet & \\
\hline sic & sicyet & \\
\hline sūyet & sūyet & \\
\hline$s n \bar{a}$ & snāyet & -snāyeyur \\
\hline
\end{tabular}

\section{precatives (a selection)}

\section{present formations} thematic athematic

kṣipáti

(grhnate, etc. $)^{44}$

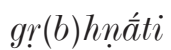

degdhi

dhyáyati

pádyate

bhajyate

bhrjjáti

mriyáte

rámate, -ti

vidáti

śámsati

śimsáti

sájati

siñcáti

sūyate

súte

snáti

śináști

átti

adyāt, adyāsam

$a s ́$ aśyās

$\bar{a} p y \bar{a} s$

rdhyās

kriyāt

gamyās

bhūyās

-bhriyāt

yujyátām,

yujyāt, etc.

śak

(


The main difference between the two lists is evident. All roots for which -yet-optatives are attested have thematic (classes I, VI, IV) presents (except dih and $s n \bar{a}$ ), whereas many roots of the second group do not. This correlation suggests the following simple explanation: -yet-optatives result from a contamination of precatives (root aorist optatives) (śisyāt, sicyāt, etc.) and thematic present optatives (śimset, siñcet, kșipét, etc.), thus being, in a sense, 'thematic precatives'. To put it differently, the rebuilding of the original root aorist optatives śisyāt, sicyāt, etc. has been triggered by the thematic present formations of the same root.

The identification of $-y \bar{a} t$ and -yet could be further supported by the parallelism of precatives and class IV present optatives derived from $\bar{a}$ roots, noticed by Hoffmann (1967: 26ff. [= 1976: 466ff.]); cf. such pairs as -vāyát (KS, KauśS) : -váyet (Taittirīya-Saṃhitā, Taittirīya-Brāhmaṇa) ( $v a \bar{a}$ "become extinguished, vanish") and dhyāáa $:$ dhyáyet.

\section{6. -yet-Optatives and Parallel Formations}

There are two optative formations which are, in some ways, parallel to the -yet-optative and important for understanding its paradigmatic status.

\section{1. -yet-Optatives and the Type gamema}

The rare aorist type gamema has been discussed and explained by Insler (1975: 6ff.); see also Renou 1940: 6ff. and Hoffmann 1955: 91 (= 1976: 386). As is well known, alongside athematic root aorist optatives like gamyās, we find gaméma (RV) and games (Vājasaneyi-Saṃhitā), alongside rdhyās, rdhyáma (RV) - rọdhema (AV), rdhet (ŚB), etc. As Insler shows, these formations result from thematicization of the root aorist optatives.

In my view, -yet-optatives have arisen due to the same tendency, i.e. due to thematicization. Like the type gamema, -yet-optatives have adopted the accentuation of the underlying root aorist optatives (ef. Hoffmann 1955: 91 [= 1976: 386]; Insler 1975: 11f.). Both of these morphological types have been created on the basis of forms in -yát, -yáma, etc. The difference between the type gamema and -yet-optatives is, in particular, of a chronological nature. While the type gamema arises already in the Mantra period, -yet-optatives appear in Vedic prose and post-Vedic texts (late Brāhmaṇas, Upaniṣads, Sūtras).

Once these morphological types were rooted in the verbal system as separate formations, they could probably be derived without the inter- 
mediary stage of the root aorist optative. Thus, for instance, we do not find the root aorist optative **kșipyát alongside kșipyet, etc.

It should be noted that 3sg. forms like labhét and ridhet may both represent formations of Insler's type gamema and - under the assumption that -yet-optatives could lose the suffixal $y$ (see $\$ 7.2$ ) - betray unattested -yet-optatives (*labhyét, *rdhyet).

\section{2. -yet-Optatives and Athematic Infixed Nasal (Class VII) Present Optatives}

There is yet another late Vedic formation closely related to the precatives in -yāt, represented by such forms as nindyāt, vindyāt, siñcyāt. This type has been briefly discussed by Hoffmann (1970: 66f. [= 1976: 517f.], n. 2). ${ }^{45}$ From the formal point of view, such forms can only be treated as optatives derived from athematic presents with the nasal infix (class VII). The main problem about such an analysis is the absence of nonoptative forms based on athematic stems (**vinátti, **sinákti, etc.). We only find thematic forms (vindáti, siñcáti), and the corresponding 3sg. optative must be vindét and siñcét, while vindyāt and siñcyāt prove isolated. Hoffmann was absolutely right in pointing out that vindyāt, etc. cannot belong with the unattested athematic nasal present (**vinátti, etc.), but his characterisation of such forms as "analogische Neubildung" does not clarify their origin. In my view, forms like nindyāt, vindyāt and siñcyāt exemplify yet another replacement of the regular root aorist optatives (precatives) with hybrid forms based on the infixed present stems. Obviously, the root aorist optatives had become unfamiliar by the late Vedic period and tended to be replaced by formations based on more common stems. Although the easiest option - thematic present optatives (vindet, siñcet, etc.) - was of course available, the authors/redactors of the texts may have been looking for forms more similar to root aorist optatives, thus creating athematic "pseudo-present" optatives of the type siñcyāt and -yet-optatives of the type sicyet (both incorporating $y$ after the root) - in imitation of the authentic root aorist optatives in $-y \bar{a} t$.

Thus, strictly speaking, forms like sincyāt should also be regarded as a separate formation, built on the same model as root aorist optatives (and functionally equivalent to these), but based on present stems - "present precatives". This analysis is also supported by their defective paradigms: like -yet-optatives, they lack other forms besides 3rd person singular - we

45 See also Oberlies 2003: 210 with n. 1. 
do not find **sincyām, etc. Neither formation can belong to the present system, for neither athematic nasal presents (of the type **sinákti), nor active -ya-presents (of the type **sicyati) are derived from the roots in question. In a sense, -yet-optatives are even less regular than athematic nasal present optatives like siñcyāt: the latter form is based on the nasal present stem, which is attested for this root - at least in its thematic variant; whereas (active) -ya-presents are not derived from the roots kșip, śams, sic, etc. at all. Moreover, the final accentuation of mrityét and bhrjyéyur shows that -yet-optatives cannot be grouped with -ya-presents even from the purely formal point of view.

\subsection{The Paradigmatic Domain of Aorist Optatives in Late Vedic}

The paradigmatic domain of aorist optatives in late Vedic and its origins can now be schematized as follows:

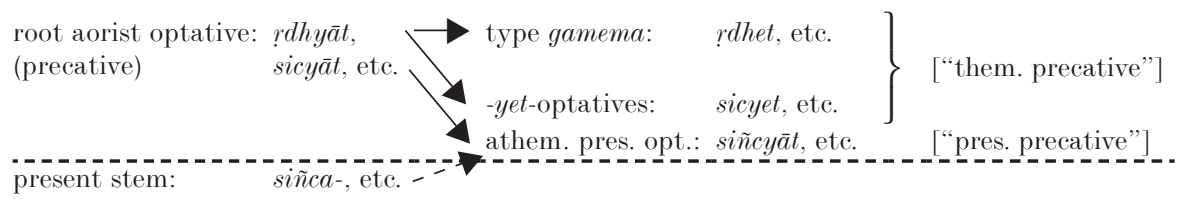

\section{Further Development and Possible Traces of -yet-Optatives}

\subsection{Evidence from Epic and Classical Sanskrit}

A number of forms in -yet can be found in the Mahābhārata and Rāmāyaṇa: ${ }^{46}$

vanāc ca vāyuh surabhih pravāyet [v.l. $\left.{ }^{\circ} v \bar{a} y \bar{a} t\right]^{47}$ (Mbh. 1.65.42a) "And let a fragrant wind blow forth from the wood ..."

46 Most of the relevant Mbh. forms I owe to Thomas Oberlies (see also Oberlies 2003: 143, 230f. et passim); a few forms (among which Mbh. 1.147 .8 vyucchidyet) are mentioned by Holtzmann (1884: 25, §774); most of the Rām. forms are taken from Sen 1949: 102.

${ }^{47}$ In formal terms, the form -vāyet might also be taken as a regular class IV present optative. In early Vedic the root ${ }^{1} v \bar{a}$ "blow" has only a class II present (váti, etc.), being paradigmatically opposed to the $\operatorname{root}^{2} v \bar{a}$ "become deficient, extinguished, vanish", which forms the class IV present váya-ti. However, from the late Vedic period onwards, vāya- ${ }^{t i}$ is also attested in the sense "blow" (in particular, in the ȘB, AĀ, JUB; see Kulikov 2001: 460), and Mbh. 1.65.42 -vāyet could belong with this secondary class IV present (see Sil 1961: 43; Oberlies 2003: 194, 510). The most important argument against this analysis is the precative form -vāya t, attested as a variant reading in a number of mss. (see crit. app. ad loc.), which indirectly supports the interpretation of -vāyet as a -yet-optative (= precative). 
tāte 'pi hi gate svargam ' vinaște ca mamānuje / pindah piț̣̄nām vyucchidyet ' tat teṣām apriyam bhavet // (Mbh. 1.147.8)

"Since, when $[\mathrm{my}]$ father has gone to heaven and my younger brother has perished, the offering to the fathers will be interrupted, [and] that will be unpleasant for them." 48

katham jāyān (v.l. jāyen) mamodare // (Mbh. 3.13.62d) "How (else) could he (sc. my husband) be born (again) from my belly!" 49

na cānuśiṣyed (v.l. 'śiṣyād) rājānam 'aprcchantam kadā cana / (Mbh. 4.4.12ab) "One should never instruct a king who does not ask (for it)."

yo hy ādriyed (v.l. ${ }^{\circ}$ driyād) bhaksyam iti śvamāmsam ' manye na tasyāsti vivarjañyam // (Mbh. 12.139.83cd) "Since for the one who would accept dog's meat as edible there will be nothing, I think, which should be avoided." 50

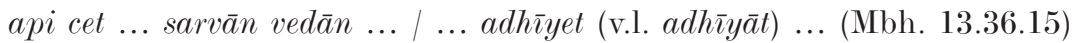

"Even if he will learn all the Vedas..."

nāvamanyed abhigatam ' na pranudyāt (v.l. ' nudyet) katham cana / (Mbh. 13.62.13ab) "One should never despise or drive away a visitor." 52

nākīrtayitvā gāh supyāt (v.l. supye ) (Mbh. 13.77.15a) "One should not go to bed without having recited [the names of the] kine."

yas trāyet tridaśān api // (Rām. 3.57.11d) "(the one) who could protect all thirty (gods)" 53

setur atra yathā badhyed ${ }^{54}$ ' yathā paśyema tām pur̄̄m / tasya rākșasarājasya (Rām. 6.2.9abc) "that a bridge is bound up here, so that we could visit the city of the Rākṣasa king."

rāghavasya yaśo hīyet (v.l. hīyāt) (Rām. 5.35.57c) "Rāghava's glory would be diminished."

48 This form is taken by Oberlies (2003: 240 and 430) as a passive with the active inflexion.

49 See Oberlies 2003: 430.

50 Oberlies (2003: 449) prefers a precative analysis of this form, and, accordingly, the reading ${ }^{\circ}$ driyāt. For another post-Vedic attestation of the form a adriyet, in Varāhamihira's Yogayātrā, see below, p. 51.

51 See Oberlies 2003: 208f., 392.

52 See Oberlies 2003: 143, 460. - For another post-Vedic attestation of the form (-)manyet in Dharmasūtras (Smṛtis), see below, p. 50f.

53 See van Daalen 1980: 95; Oberlies 2003: 442.

${ }_{54}$ V.ll. badhyetātha yathā setur; setur badhyeta hi yathā. For this form see Sen 1964: 201 (where it is explained as "due to MIA [= Middle Indo-Aryan] influence") and Oberlies 2003: 241, 469. 
Strictly speaking, the argumentative validity of the Epic forms in -yet is somewhat weaker than for the evidence from Vedic. While in Vedic and (early) post-Vedic texts middle -ya-presents (passives) with the irregular active inflexion are exceptional, in Epic Sanskrit they become more common (albeit still fairly rare), and some forms quoted above can be explained as replacements of regular middle present (passive) optatives (i.e. ${ }^{+}$trāyeta, ${ }^{+}$badhyeta, etc. - which are indeed attested in some cases as variant readings) - sometimes for metrical reasons. Yet, this explanation does not work for all such forms. The strongest evidence for Epic-yet-optatives is furnished by occurrences for which mss. attest the regular precative form in -yāt alongside a form in -yet, as is the case with

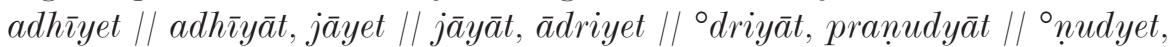

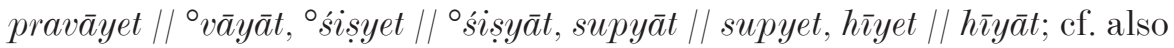
Mbh. 4.47.9 khyāyet, v.l. khyāyāt.

Next to these supposed Epic -yet-optatives, there are a few forms in -yet attested in the Smrti literature, which thus belong to approximately the same chronological level and can equally be explained as replacements of regular middle forms for metrical reasons:

saṃviśet tūryaghoṣeṇa ' pratibudhyet tathaiva ca / (YājñSmṛ. 1.330ab [ed. Pāndey 1.331ab]) "He should go to bed to the music of instruments, and so should he wake up."

The middle -ya-present budhya-te "wake" is well attested from the RV onwards. Apart from the unclear atharvavedic form ${ }^{+}$búdhyema (Roth Whitney's conjecture for AV 19.67.3, mss. bú(d)dhema, búdhrema), which may have emerged under the influence of the adjacent active optatives páśyema, bhávema, etc. ${ }^{55}$ active forms of the -ya-present búdhya-te do not occur in the Vedic period. In the Sūtras we only find the active participle pra-budhyant- in Mānśs 2.1.3.11.

Another Smrti form in -yet which is relevant for our discussion is manyet:

tam vai manyet pitaram mātaram ca ' tasmai na druhyet kṛtam asya jānan // (ViṣSmṛ. 30.47ed VāsDhS 2.10 = HirDhS 1.1.18) " "[The student], indeed, should consider him (sc. his teacher) as (his true) father and mother; he should not grieve him, acknowledging what he (sc. his teacher) has done [for him].'”

55 See Insler 1975: 7, n. 13; Gotō 1987: 220.

56 The parallel verses in the VāsDhS and HirDhS use the corresponding middle form instead (tam manyeta ...; see, for instance, Olivelle 2000: 356 and 637), and this reading is adopted by Krishnamacharya. 
The -ya-present mánya- "think" is well attested from the RV onwards, but does not occur with the active inflexion until the Upaniṣad and Sūtra period (see Gotō 1997: 1016). ${ }^{57}$

Although both -budhyet and manyet could be explained as built under the influence of the adjacent active optatives (-viset and druhyet, respectively), we cannot rule out that they are -yet-optatives.

One more form, which may represent a -yet-optative, and is also attested in a post-Vedic metrical text, Varāhamihira's Yogayātrā (ed. H. Kern), is -driyet:

daivajñamantrisuhṛāptavacāmsi rājōa' yo nādriyet svamaticeștitaduștabuddhih / (Yogayātrā 2.9ab; see Kern 1868: 168 [= 1913: 104]) "Ein König, der die Worte seiner Astrologen, Minister, Freunde und Vertrauten nicht beachtet, indem er eigensinnig verfährt und unrichtig urtheilt ..." (Kern 1868: $183[=1913: 126])$.

Kern (1868: 201 [= 1913: 156]) noticed the irregularity of the active ending in $\bar{a}$-driyet. Although one of the mss. has the middle optative instead $\left({ }^{\circ}\right.$ yeta mati $^{\circ}$ ), the editor has adopted the reading ${ }^{\circ}$ driyet, since the absence of $s v a^{\circ}$ in the following word renders the whole compound meaningless.

On the Epic attestation of adriyet (Mbh. 12.139.83), see above. ${ }^{58}$

57 The two active forms attested in the Upanișads and Sūtras are abhimanyanti MuṇuU 1.2.9 "they think, imagine" (see Salomon 1981: 97; Olivelle 1998: 441) and part. ava-manyant- BaudhŚS 29.8: 380.13. The form ava-manyet, quoted in $V W C-S \bar{u}$. I/394b as attested in VaikhDhS 3.3.6 and mentioned by Bharadwaj (1982: 108), may be based on a misunderstanding. Ed. Caland (3.3: 134.12) has the regular middle optative (devān vedān rājagurumātāpiț̣nn vidvadbrāhmanān nāvamanyeta na nindet "He should not despise, nor blame the gods, the Vedas, the king, his teacher, his mother and father, learned Brahmanas"), with no variant readings (note that in Bharadwaj's [1982] bibliography only Caland's ed. is mentioned). The two Indian editions used by Caland, as well as the Madras edition, to which $V W C-S \bar{u}$. refers, were unavailable to me. Active forms of mánya- ${ }^{\text {telti }}$ become more common in Epic Sanskrit (see Gotō 1997: 1016; Oberlies 2003: 163); cf., in particular, Mbh. 13.62.13 avamanyet quoted above, p. 49.

58 Yet another form attested in a metrical text, which may be worthy of discussion, is 3pl. opt. -līyeyur met with in the relatively late Mārkaṇdeya-Purāṇa: tasmāc chyenādayo yasya ' nilīyeyuh śirasy atha (MārkP 51.69cd) "therefore he, on whose head a hawk and other [birds] would alight". Although active forms of the -ya-presents " ${ }^{1} \bar{y} y-{ }^{\mathrm{te} /(t i)}$ "adhere, cling" and "líya-te/(ti) "dissolve, disappear" (see Werba 1997: 315) do occur from the postVedic period onwards (on one attestation in the "principal" Upaniṣads, Muṇ̣U 3.2.2 pra-vi-līyanti, see Salomon 1981: 98; a few forms occur in later texts, e.g. Rām. 6.102.33a

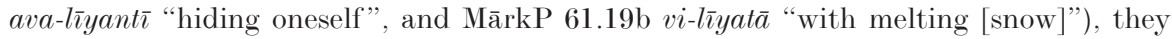
remain very rare. Furthermore, -līyeyur cannot be explained as a replacement metri causa of the middle optative -liyeran (which has the same metrical scheme). Note, incidentally, that both active forms of the -ya-present of the compound ni-li quoted in $P W$ VI/551 are 3rd person optatives: ni-līyeyur, ni-līyet. 
Besides a few forms from metrical texts listed above, worthy of mention is $3 p l$. opt. vi-trudyeyur, with which an indigenous commentator glosses the transitive virujeyur at KātyŚS 22.3.22 dakșinākāle kantakair enā virujeyuh "[the priests] should prick them (sc. the cows) with thorns at the time of daksina $\bar{a}$ [-distribution]". The active -ya-present of the late (Class. Skt.) root trut is employed intransitively ("break, come into pieces"). ${ }^{59}$ The transitive syntax of -trudyeyur (derived from the root variant trud) can be explained under the assumption that this form belongs with the -yet-optatives, not with the -ya-presents; see $\$ 4.2 .{ }^{60}$

\subsection{Possible Indirect Reflexes of -yet-Optatives}

Both in late Vedic and post-Vedic periods, -yet-optatives remain extremely rare. Most likely, this formation was considered too awkward to become a productive morphological type. Being morphologically indistinguishable (in unaccentuated texts) from -ya-present optatives and lacking any specific function different from that of present optatives, it had little chance to survive. What could become of these forms? On the one hand, some -yet-optatives may have been replaced with much more familiar and productive -ya-passives, with the concomitant restructuring of the syntax of the corresponding sentence; cf. the discussion of the passive optative form nir-mrjyeran in GB 1.4.13: 104.13f., where the passive construction yajamāna nirmrjyeran "the sacrificers would be wiped off" is based on ŚB 12.1.3.23 té vimrityeyuh "they would fall to pieces" (see above, s.v. mrit [p. 37, n. 27]). On the other hand, in some yet-optatives, the segment $y$ could have been assessed as a secondary insertion, especially if the root in question also formed class VI presents (as in the case of bhrj(j)yéyur // bhrjjáti; see s.v. bhrj above, p. 35). The co-existence of -yet-optatives $(\sqrt{ }$-yét, $\sqrt{ }$-yéyur) with forms without $y$ (i.e. class VI present optatives: $\sqrt{ }$-ét, $\sqrt{ }$-éyur) could favour the secondary association of -yet-optatives with class VI presents. The $\sqrt{ }$-yét // $\sqrt{ }$-ét $\bmod$ el could probably trigger the loss of $y$ also in the individual verbal systems where, originally, class VI presents were lacking. In particular, traces of -yet-optatives can possibly be found among active optatives

59 For this present, see $P W$ III/451f.; Tedesco 1953: 80f.; Balbir 1982: 66.

60 The very rare irregular forms in -yet in Classical Sanskrit, mostly attested as variant readings (for instance, Pañc. 2.118: 154.18 na parityajyet, for the correct -tyajet "[he] should not quit ...", see Hertel 1912: 143 and Sternbach 1956: 124; KubjT 23.134 prapüjyet [ms. D], for the correct prapüjyeta, see ed. Goudriaan - Schoterman, p. 81), are likely to result from scribal errors. 
built on thematic root present stems (classes I and VI) which are unattested or exceptional with the active inflexion; cf. the list of such forms in Gotō 1987: 396f. This may be the case for graset SVB 2.3.11 ( middle pres. grásate), saheyur $\hat{S}_{\bar{A}}^{m} 12.7$ (32) ( middle pres. sáhate), which may betray unattested -yet-optatives (*grasyet, *sahyeyur) ${ }^{61}$

In some cases the loss of $y$ in hypothetical -yet-optatives may have given rise to secondary thematic root presents (class VI). ${ }^{62}$ Such may be the origin of the class VI present -usa- $a^{t i}$ "burn", which appears in late Vedic $(\mathrm{GB})$ and in the Sūtras alongside the old class I present ós $a^{-}{ }^{i}$. Gotō (1987: 109f.) accounts for this formation as resulting from the reanalysis of imperfect forms in compounds with upa (*uposat $<<u p a$-ausat). This assumption is plausible but does not explain why the majority of the attested forms are 3sg. and pl. optatives in -et and -eyur. Assuming that -uset, -useyur go back to hypothetical -yet-optatives (*-usyet, *-usyeyur), we are able to account for this imbalance of moods.

\subsection{Evidence from Middle Indo-Aryan}

Although -yet-optatives have not become a productive formation, it makes sense to look for their traces in later texts and in Middle IndoAryan. In particular, here probably belongs the much debated form hamñeyasu/hamñeyu, attested in the famous Aśokan Rock Edict XIII (N). Most interpreters noticed the morphological irregularity of this form and translated the end of the sentence (in the Shāhbāzgarhī version: ... na ca [ha]ṃneyasu ${ }^{63}$ as a passive construction: "in order that

${ }^{61}$ Some of the 3sg. forms in -ét, such as RVKh. 3.172.2 labhét (which cannot be a correct optative form of the middle class I present lábhate; note especially the abnormal final accentuation, see Gotō 1987: 262), can be accounted for otherwise - as belonging to Insler's type gamema (see above, \$6.1). In general, this analysis is more probable for forms attested in the mantras, where the type gamema first appears; on the contrary, for late Vedic and post-Vedic forms an explanation in terms of -yet-optatives seems preferable.

${ }^{62}$ The loss of $y$ before $e$ is also attested (from the Sūtras onwards) in 3sg./pl. optatives of syati ( $\sqrt{s}_{\bar{a}}$ "bind") and asyati ( ${ }_{\text {as }}$ "throw"); cf. -set (in adhyava-set BaudhŚS 21.11: 88.18-19, KauśS 137.1, Mbh.), -aset (e.g., in ny-aset MānŚS 10.3.5.22, 11.7.1.6²×, ManuSmṛ. 6.46, YājñSmṛ. 2.103, 3.35, BhāgP 7.12.24; abhy-aset ĀpDhS 1.27.8 [ح HirDhS 1.7.33 abhy-asyet, ef. Renou 1947: 193]; etc.); see also Böhtlingk 1896: 249f.; Leumann 1968: 58; Biswas 1968: 74, 171. The loss of $y$ in compounds has probably been supported by dissimilation processes after preverbs in -i/-y; see Leumann 1968: 58, Gotō 1987: 85, Oberlies 2003: 197 with n. 3, and Kulikov 2005: 307f. for details. In Epic Sanskrit we also find non-optative forms for both of these newly-built class I presents; see Whitney 1885: 5, 185 and Oberlies 2003: 197, 202, 390, 531.

63 For a synopsis of versions, see Schneider 1978: 75 and 116. 
they may not be killed" (Hultzsch 1925: 69) ${ }^{64}$ - which makes little sense in the context, however. Caillat $(1991$ : 11; 1992) has convincingly demonstrated that Bloch's (1950: 129) transitive translation "qu'ils cessent de tuer" is more attractive, and that hamñeyasu/hamneyu is a "mixed" optative form. Thus, the gemination betrays $y$ of the optative suffix (ef. Skt. hanyāt), not of the -yá-passive, while $e$ must be yet another mark of the optative (whence Caillat's term "double optative suffix"). In my view, Sanskrit -yet-optatives can further clarify the morphological status of the Aśokan form in question, which can readily be explained as a trace of (or a formation parallel to) the plural -yet-optative of han, i.e. Skt. *hanyeyur. The most direct reflex of the supposed Old Indo-Aryan form would be hamneyu (hamñeyu), which seems to have been preserved in two versions (Erragudi and Kālsī) and is adopted by Schneider (1978: 75 and 116) for the prototext. To the same morphological type must belong Pāli optative hañne (< Skt. *hanyet) "one should kill", which thus supports the transitive analysis of Aśokan hamneyu/hamñeyasu. The Pāli 3sg. optatives pakampiye "he will bend", maddiye "he shall crush" and haññe "he should kill" have been correctly evaluated already in CPD I/517, s.v. asnāti as "mixed pot.[ential]s"; see also Smith 1951: 4 ("formes contaminées du type-kampiye $(<-$ kampet $\times$-kampyāt)") and Oberlies 2000: 227f. In my view, these forms point to the Pāli formation, corresponding to the Skt. -yet-optative. ${ }^{65}$

\section{Synopsis of Forms and Conclusions}

For the sake of convenience I list all forms discussed above as well as hypothetical -yet-optatives:

${ }^{64}$ Likewise Edgerton (1952: 117), contra Bloch (1950: 129) and Schneider (1978: 117): "damit sie ... nicht getötet werden"; cf. also Schneider's comments on p. 150.

65 I would like to thank Thomas Oberlies for having drawn my attention to these Pāli and Aśokan forms. 


\section{Attested Forms}

1. $i$ "go"

2. kssip "throw"

3. chid "break, hurt"

4. grh "seize"

5. trā "rescue"

6. trut (trud) "break"

7. dih "besmear"

8. dr "heed"

9. dhyā "think"

10. nud "push"

11. pad "fall"

12. bandh "bind"

13. budh "wake"

14. bhañj "break"

15. bhrj(j) "roast"

16. man "think"

17. $m r$ "die"

18. mrj "wipe off, destroy"

19. mrit "decay"

20. ram "stop"

21. li "adhere"

22. va "blow"

23. vid "know"

24. śams "recite"

25. śa $s$ "teach"

26. śis "leave"

27. sañj "attach"

28. sic "pour"

29. sü "beget"

30. sn "bathe"

31. svap "sleep"

32. hä "abandon"

33. us "burn"

34. kamp "tremble"

35. gras "devour"

36. mrd / mard "crush"

37. sah "prevail"

38. han "kill" $-\bar{r}$ yet Mbh.

kssipyet $\mathrm{ChU}$

chidyet Mbh.

grhyet Kauśs ${ }^{m}$

trāyet Rām.

-driyet Mbh., Yogayātrā

dhyāyét RVKh.

-nudyet Mbh.

+ ${ }^{+}$padyet Ārṣ U

badhyet Rām.

-budhyet YājñSmr.

-bhajyet MānGS

manyet VișSmr., Mbh.

mriyet AmrtU

-mrjyet $\mathrm{GB}$

-mrityét ŚSB $(\approx \mathrm{GB})$

-ramyet BaudhŚS

-mrityeyur ŚSB

-lāyeyur MārkP

vāyet Mbh.

vidyet JābU

-śasyet SŚS

-śisyet Mbh.

śisyet GB (= VaitS), Vaikh/ Bhārśs

${ }^{(+)}$-sajjet MānŚS

sicyet $\mathbf{S} \overline{\mathrm{A}}$

sūyet AVPar.

snāyet Mānavānugrāhika -snāyeyur GB sūtra

supyet Mbh.

hīyet Rām. -dihyet Bhārśs

-trudyeyur KātyŚSBh.

bhrjj(j)yéyur $\mathrm{M} / \mathrm{KS}$

\section{Hypothetical Forms}

*usyet $(\rightarrow$ uset, class VI pres. usati GB, Sū.)

*kampyet (> Pāli pakampiye)

*grasyet $(\rightarrow$ graset $\mathrm{SVB})$

*mrdyet (> Pāli maddiye)

*hanyet (> Pāli hañne) *sahyeyur $(\rightarrow$ saheyur $\mathbf{S} \overline{\mathrm{A}})$

*hanyeyur (> Aśoka hamneyu, etc.) 
Let us recapitulate the main arguments pro and contra -yet-optatives as a separate morphological formation. Of course, from the formal point of view, forms in -yet- could be regarded simply as active optatives based on class IV presents; but in most of the cases discussed above this analysis is impossible.

The strongest evidence for positing -yet-optatives as a separate formation is furnished by the verbs which have no non-passive (class IV) -yapresents at all: forms like -śasyet or kșipyet can by no means be grouped with -yá-passives and therefore prove to be isolated within the corresponding verbal systems.

Evidence for -yet-optatives of those verbs from which class IV (non-passive) presents do derive - albeit with the middle inflexion - is somewhat weaker. Forms like -driyet, manyet, mriyet and sūyet can of course be (and usually are) explained as instances of diathesis confusion (middle/ active) in late Vedic and post-Vedic texts - i.e. as replacements of the original middle optatives ${ }^{+}$manyeta,${ }^{+}$mriyeta,${ }^{+}$sūyeta, etc. Such an explanation is possible, particularly, in the cases where non-optative forms are attested already from the late Vedic or early post-Vedic periods onwards. ${ }^{66}$ However, this analysis does not account for the total absence of other active forms (**mriyati, **suyati; part. **mriyant-, **süyant-, etc.) from the paradigm or the unusual imbalance of moods.

Finally, positing -yet-optatives as a separate formation renders a number of emendations unnecessary:

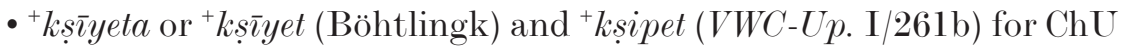
8.6.5

- ${ }^{+}$dhyáyet (VWC-Sa. III/1744a) for RVKh. 3.10².16

- ${ }^{+}$padyan (?) (VWC-Up. II/773a) for ĀrșU

- ${ }^{+}$bhajet (ed. Sastri) or ${ }^{+}$-bhujet (Falk) for MānGS 2.15.6

- ${ }^{+}$bhrjjéyur $(P W)$ for MSp 1.10.11: 151.6 $\mathrm{KS}^{\mathrm{p}}$ 36.6: 73.1

- ${ }^{+}$-mríty ${ }^{\circ}$ (Delbrück) for SB -mrityét

- ${ }^{+}$śisyeta (Caland) for VaikhŚS 21.4: 325.2

- ${ }^{+}$śsisyeta $(V W C-S \bar{u}$. I/628b) for BhārŚs 7.3.9

${ }_{66}$ Thus I do not include into my corpus the form dahyet (MānGS 2.15.6, late Up.), which belongs with the middle present dahya- ${ }^{t e}$, since the active non-optative forms are attested from the late Brāhmaṇas onwards (dahyanti ȘB 5.9.2) and become quite common in Epic Skt.; see Holtzmann 1884: 25f.; Kulkarni 1943: 239. Likewise, vāśyet (mss. $v \bar{a} s y^{\circ}$ ) in APrāyaśc. 2.4 (cf. also Caland's conjecture ${ }^{+} v \bar{a} s ́ y e[t]$ for JGS 2.7: 32.7 [ms.] "vāsapec ${ }^{\circ}$ ), which corresponds to the middle optative vāsyeta (váśsya- "low, bellow") in the parallel Brāhmaṇa passages ŚB 12.4.1.12 AB 5.27.6 = 7.3.3, occurs adjacent to the indicative form vāśyati, being therefore of lesser value for our purpose. 
- ${ }^{+}$sajet (ed. van Gelder) for MānŚS 1.1.3.6

- ${ }^{+}$sicyeta (Keith, ed. Bhim Dev, VWC-Br. II/1590a) for ŚĀ 8.2.

To sum up, evidence for -yet-optatives appears rather scant: thus far I have found about 30 forms. It should be noted, however, that the unusual morphological character of -yet-optatives may have caused editors and interpreters of texts to emend most such forms, treating them either as class IV optatives with the irregular active ending, or as class VI optatives (with a secondary $y$ ). Thus, some -yet-forms may merely have been emended, leaving no traces in editions with minimal critical apparatus. A thorough search into the ms. sources and into variant readings adduced in critical apparatuses will probably furnish further evidence for -yet-optatives.

\section{Literature}

\section{Primary Literature - Text Editions}

$\mathrm{A} \bar{A}$

$\mathrm{AB}$

$\bar{A}$ gnivGS

AmṛtU

$\bar{A} p D h S$

APrāyaśc.

$\bar{A} p S ́ S$

$\bar{A} r s \underline{U}$
The Aitareya Äranyaka. Edited ... with introduction, translation, notes, indexes and an appendix containing the portion hitherto unpublished of the Śānkhāyana Āranyaka by A.B. Keith. [Anecdota Oxoniensia, Aryan Series I/9]. Oxford: Clarendon Press, 1909.

Das Aitareya Brāhmana. Mit Auszügen aus dem Commentare von Sāyanāeārya und anderen Beilagen hrsg. von Theodor Aufrecht. Bonn: Adolph Marcus, 1879.

Āgniveśyagṛhyasūtra, ed. L.A. Ravi Varma. [Trivandrum Sanskrit Series 144]. Trivandrum 1940.

Amṛtanāda-Upaniṣad, in: YogaU, p. 11-25.

Amṛtanāda-Upaniṣad, in: Upanișadām Samuccayah, ed. H.N. Āpte. [ĀnSS 29]. Poona ${ }^{2} 1925$, p. 43-69.

Amṛtanāda-Upaniṣad, in: 120Up., p. 169-170.

A pastambīyadharmasūtram. Aphorisms on the Sacred Law of the Hindus by A pastamba, ed. G. Bühler. 2 parts. [Bombay Sanskrit Series 44 \& 50]. Bombay: Government Central Book Depôt, ${ }^{2} 1892-1894$.

Atharvaprāyaścittāni. Text mit Anmerkungen, von J. von Negelein. JAOS 33 (1913) 71-144 \& 217-253; 34 (1915) 229-277.

The Śrauta Sútra of Ápastamba Belonging to the Taittiriya Samhitá with the Commentary of Rudradatta, ed. R. Garbe. 3 vols. [BInd 92]. Calcutta 1882-1902.

Ārșeya-Upanișad, in: Belvalkar 1925, p. 31-35.

Ārșeya-Upaniṣad, in: Upanișat-samgrahah Containing 188 Upaniṣad, ed. with Sanskrit introduction by J.L. Shastri. Dillī 1970, vol. II, p. 7-9. 
Atharva Veda Sanhita. Herausgegeben von R. Roth und W.D. Whitney. Zweite verbesserte Auflage besorgt von Max Lindenau. Berlin: Ferd. Dümmler, 1924.

AVPar.

BaudhŚS

The Parisistas of the Atharvaveda, ed. G.M. Bolling and J. von Negelein. 2 vols. Vol. I: Text and Critical Apparatus. Leipzig: Harrassowitz, 1909-1910.

BhāgP

BhārŚs

The Baudháyana Śrauta Sútra Belonging to the Taittiríya Saṃitá, ed. W. Caland. 3 vols. [BInd 163]. Calcutta 1904-1924.

The Baudhāyana Śrautasūtra, ed. \& tr. C.G. Kashikar. 4 vols. [Kalāmūlaśāstra-granthamālā 35-38]. Delhi: Indira Gandhi National Centre for the Arts - Motilal Banarsidass, 2003.

Le Bhâgavata Purâna, ou Histoire poétique de Krŭchṇa, traduit et publié par E. Burnouf [et M. Hauvette-Besnault]. Paris 1884-1898.

The Śrauta, Paitrmedhika and Pariśeșa Sūtras of Bharadvāja. Critically edited and translated by C.G. Kashikar. 2 parts. Poona: Tilak Maharashtra Vidyapeeth, 1964.

Br.

Brāhmaṇa(s)

$\mathrm{BD}$

$\mathrm{ChU}$

The Bṛaddevatā Attributed to Śaunaka. A Summary of the Deities and Myths of the Rig-Veda, critically ed. in the original Sanskrit with an introduction and seven appendices, and transl. into English with critical and illustrative notes by A.A. MacDonell. [HOS 5-6]. Cambridge, Mass.: Harvard University Press, 1904.

Ḱhândogjopanishad. Kritisch herausgegeben und übersetzt von O. Böhtlingk. Leipzig: Haessel, 1889.

Chāndogya-Upanișad. Traduite et annotée par É. Senart. Paris: Les Belles Lettres, 1930.

Chāndogya-Upanișad. Versuch einer kritischen Ausgabe mit einer Übersicht über ihre Lehren, von W. Morgenroth. Diss. Jena 1958.

GautPS

Gautamapitṛmedhasūtra, in: The Pitrmedhasūtras of Baudhāyana, Hiranyakeśin, Gautama, ed. with critical notes and index of words by W. Caland. [AKM X/3]. Leipzig: Brockhaus, 1896.

GB

Das Gopatha Brāhmana, hrsg. D. Gaastra. Leiden: Brill, 1919. The Gopatha Bráhmana of the Atharva Veda in the Original Sanskrit, ed. Rájendralála Mitra - Harachandra Vidyábhushana. [BInd 69]. Calcutta 1872.

HirDhS Hiranyakeśi-Dharma-Sūtra, in: HirŚs, Pt. 10 (= HirŚS XXVIXXVII).

HirŚS

Satyāṣā dhaviracitam ŚSrautasūtram, ed. Kāśīnātha Śāstrī Āgāśe and Śańkara Śāstrī Mārūlakara. 10 vols. [ĀnSS 53]. Poona 1907-1932.

JābU Jābāla-Upaniṣad, in: MinorU, p. 57-72. 
JGS

JUB

KātyŚS

KātyŚSBh.

Kauśs

KauṣGS

$\mathrm{KB}$

KS

KubjT

MānGS

MānŚs

ManuSmṛ.

MārkP
Jaiminīyagṛhyasūtra, in: Willem Caland, De literatuur van den Sāmaveda en het Jaiminigrhyasūtra. [Verhandelingen der Koninklijke Nederlandse Akademie van Wetenschappen te Amsterdam, Afdeling Letterkunde, N.R. VI/2]. Amsterdam: J. Müller, 1905 .

The Jāimin̄̄ya or Talavakāra Upaniṣad Brāhmana. Text, Translation, and Notes, ed. H. Oertel. JAOS 16 (1896) 79-260.

Jaimin̄̄yārșeya - Jaimin̄yyopanișad Brāhmanas, ed. B.R. Sharma. [Kendriya Sanskrit Vidyapeetha Series 5-6]. Tirupati: Kendriya Sanskrit Vidyapeetha, 1967.

Jaiminīya-Upaniṣad-Brāhmaṇa, in: 18Up. (ed. Limaye - Vadekar), p. 377-474.

The Crautasîtra of Kâtyâyana with Extracts from the Commentaries of Karka and Yâjnikadeva, ed. A. Weber. Berlin - London: Ferd. Dümmler, 1859.

Bhāṣya (Commentary) on KātyŚS, in: KātyŚs, ed. Weber.

The Käuçika-sūtra of the Atharva-veda with Extracts from the Commentaries of Dārila and Keçava, ed. M. Bloomfield. [JAOS 14]. New Haven: American Oriental Society, 1890.

The Kaus̄itaka Grhyasūtras with the Commentary of Bhavatrāta, ed. T.R. Chintamani. University of Madras 1944.

Kaușītaki-Brāhmaṇa, hrsg. von E.R. Sreekrishna Sarma. 1. Text. Wiesbaden: Franz Steiner, 1968.

Das Kaushîtaki Brâhmana. Herausgegeben und übersetzt von B. Lindner. I. Text. Jena: Hermann Costenoble, 1887.

Kâthakam. Die Saṃhitâ der Katha-Çâkhâ, hrsg. von L. von Schroeder. 3 Bde. Leipzig: Brockhaus, 1900-1910.

The Kubjikāmatatantra. Kulālikāmnāya Version, ed. T. Goudriaan - J.A. Schoterman. [Orientalia Rheno-Traiectina 30]. Leiden: Brill, 1988.

Das Mānava-grhya-sūtra nebst Commentar in kurzer Fassung, hrsg. von F. Knauer. St. Petersburg 1897.

Mānava-grhya-sūtra of the Maitrāyañya Śākhā with the Commentary of Astāvakra, ed. R.H. Sastri. Baroda (?) 1926. (repr.: [Panini Vaidika Granthamala 6]. New Delhi 1982).

Das Mānava-Çrauta-Sūtra, hrsg. von F. Knauer. Vol. I-III. St.Pétersbourg 1900-1903.

The Mānava Śrautasūtra Belonging to the Maitrāyaṇ̄ Saṃhitā, ed. \& tr. J.M. van Gelder. 2 vols. [Śatapitaka Series 17 \& 27]. New Delhi 1961-1963.

Mânava Dharma-śâstra. The Code of Manu, ed. according to the standard Sanskrit commentaries by J. Jolly. London: Trübner, 1887.

The Mârcandeya Purāna, ed. K.M. Banerjea. [BInd 29]. Calcutta 1862 . 
Mbh.

MinorU

MS

Muṇụ

NidānaS

Pañc.

Rām.

RV

RVKh.

Sa.

Sū.

SVB

ŚĀ

ŚB $(\mathrm{M})$

ŚBK

ŚGS
The Mahābhārata for the first time critically ed. by Vishnu S. Sukthankar et al. Poona: Bhandarkar Oriental Research Institute, 1933-1966.

The Minor Upanisads, ed. for the Adyar Library (Theosophical Society) by F.O. Schrader. Vol. I: Samnyāsa-Upanișads. [The Adyar Library 3]. Madras: The Adyar Library, 1912.

Mâitrâyaṇ̂ Samhitâ, hrsg. von L. von Schroeder. 4 Bde. Leipzig: Brockhaus, 1881-1886.

Mundaka-Upanisad. Kritische Ausgabe. Hrsg. von J. Hertel. [Indo-Iranische Quellen und Forschungen 3]. Leipzig: Haessel, 1924.

Nidāna-Sūtra of Patañjali, ed. K.N. Bhatnagar. Lahore 1939.

The Panchatantra. A Collection of Ancient Hindu Tales, ed. J. Hertel. [HOS 11]. Cambridge, Mass.: Harvard University Press, 1908.

The Vālmōki-Rāmāyaṇa critically ed. for the first time by G.H. Bhatt et al. Baroda: Oriental Institute, 1960-1975.

Die Hymnen des Rigveda, hrsg. von T. Aufrecht. 2 Bde. Bonn: Marcus, ${ }^{2} 1877$.

Die Apokryphen des Rgveda, hrsg. von I. Scheftelowitz. [Indische Forschungen 1]. Breslau: Marcus, 1906.

Saṃitā(s)

Sūtra(s)

Sāmavidhāna Brāhmana with Vedārthaprakāsa of Sāyaṇa and Padārthamātravivrti of Bharatasvāmin, ed. B.R. Sharma. [Kendriya Sanskrit Vidyapeetha Series 1]. Tirupati 1964.

Śāìkhāyanāranyakam, ed. Bhim Dev. [Vishveshvaranand Indological Series 70]. Hoshiarpur: Vishveshvaranand Vedic Research Institute, 1980.

Rqvedāntargatam Śǟikhāyanāranyakam. [ĀnsS 90]. Poona 1922.

Śāìkhāyanāranyakam, in: AĀ, ed. Keith, p. 305-328.

The Catapatha-Brâhmana in the Mâdhyandina-Çâkha with Extracts from the Commentaries of Sâyana, Harisvâmin and Dvivedaganga, ed. A. Weber. Berlin - London: Ferd. Dümmler, 1885.

The Śatapatha Brāhmana in the Kānvīya Recension, ed. W. Caland. 2 volumes. Lahore: Punjab-Sanskrit Book Depot, 19261939.

Kānvaśatapathabrāhmaṇam, ed. [\& tr.] C.R. Swaminathan. Vol. I-IV. (Kālamūlaśāstra-granthamālā 12, 22, 30 \& 31). Delhi: Indira Gandhi National Centre for the Arts - Motilal Banarsidass, 1994-2001.

Das Çâñkhâyanagṛihyam, hrsg. von H. Oldenberg. Indische Studien 15 (1878) 1-166. 
ŚŚ́S

SB

$\mathrm{TA}$

Up.

VaikhDhS

VaikhGS

VaikhŚS

Vaits

VāsDhs

ViṣSmr.

YājñSmr.

YogaU

$120 \mathrm{Up}$.

$18 \mathrm{Up}$.
The Śä̀nkhāyana Śrauta Sūtra Together with the Commentary of Varadattasuta Anartīya. Vol. I: Text of the Sütra, Critical Notes, Indices, ed. A. Hillebrandt. [BInd 99]. Calcutta 1988.

Ṣadviṃśabrāhmanam Vijñāpanabhāsyasahitam, ed. H.F. Eelsingh. Leiden: Brill, 1908.

Kṛṣayajurved̄̄yam Taittirīyāranyakam Śrīmat-Sāyaṇācāryaviracita-Bhāsya-sametam, ed. H.N. Āpțe. [ĀnSS 36]. Pune 18971898.

Upaniṣad(s)

Vaikhānasa-Dharma-Sūtra, in: VaikhGS, p. 112-145 (= VaikhGS VIII-X).

Vaikhānasasmārtasūtram. The Domestic Rules of the Vaikhānasa School Belonging to the Black Yajurveda, ed. W. Caland. [BInd 242]. Calcutta 1927.

Vaikhānasa-Śrautasūtram, ed. W. Caland. [BInd 265]. Calcutta 1941.

Vaitâna Sūtra. The Ritual of the Atharvaveda, ed. with critical notes and indices by R. Garbe. London: Trübner \& Co., 1878.

Śrīvāsisthadharmaśāstram. Aphorisms on the Sacred Law of the Aryas, as taught in the School of Vasishtha, ed. with critical notes, an Anukramanikâ, indices of words and Vedic mantras, and an appendix of quotations as found in some Dharmanibandhas by A.A. Führer. [Bombay Sanskrit Series 23]. Bombay: Government Central Book Depôt, 1883.

Viṣusmrtih. The Institutes of Vishnu Together with Extracts from the Sanskrit Commentary of Nanda Pandita called Vaijayantá, ed. with critical notes, an Anukramaniká, and indexes of words and mantras by J. Jolly. [BInd 91]. Calcutta 1881.

Viṣusmrti with the Commentary Keśavavaijayantī of Nandapandita, ed. V. Krishnamacharya. 2 vols. [Adyar Library Series 93]. Madras 1964.

Yājñavalkyadharmaśāstram. Yâjñvalkya's Gesetzbuch. Sanskrit und Deutsch hrsg. von A.F. Stenzler. Berlin - London: Ferd. Dümmler, 1849.

Yājñavalkyasmṛti of Yogīshwara Yājñavalkya with the Mitāksarāa Commentary of Vijñaneshwar, ed. with the 'Prakash' Hindī Commentary by Umesh Chandra Pāndey. [Kashi Sanskrit Series 178]. Varanasi: Chowkhamba Sanskrit Series Office, 1967.

The Yoga Upanishads with the Commentary of Sri UpanishadBrahma-Yogin, ed. A. Mahadeva Sastri. Adyar 1920.

İśādivimśsottaraśatopanișadah (A Compilation of Well-Known 120 Upanisads), ed. N.R.K. Acarya. Mumbai: Nirṇayasāgara, ${ }^{5} 1948$.

Eighteen Principal Upanisads. Upanisadic Text with Parallels from Extant Vedic Literature, Exegetical and Grammatical 
Balbir 1982

Bartholomae 1925

Belvalkar 1925

Bharadwaj 1982

Biswas 1968

Bloch 1927

Bloch 1950

Böhtlingk 1876

Böhtlingk 1896

Böhtlingk 1897

Bollée 1956

Burrow 1954
Notes, ed. V. P. Limaye-R. D. Vadekar. Poona: Vaidika Saṁśodhana Maṇdala, 1958.

\section{Secondary Literature}

Nalini Balbir, Dānâștakakathā. Recueil jaina de huit histoires sur le don. Introduction, édition critique, traduction, notes. [PICI 48]. Paris: Institut de Civilisation Indienne - E. de Boccard, 1982.

Christian Bartholomae, Zur Kenntnis der mitteliranischen Mundarten 6. [Sitzungsberichte der Heidelberger Akademie der Wissenschaften. Philosophisch-Historische Klasse XV/6]. Heidelberg: Winter, 1924-1925.

Sripad Krishna Belvalkar, Four Unpublished Upanișadic Texts, tentatively edited and translated for the first time. Proceedings and Transactions of the 3rd Oriental Conference (Madras 1925) 17-40.

Sudhi Kant Bharadwaj, Linguistic Study of Dharmasūtras. Rohtak: Manthan Publications, 1982.

Ashutosh Sarma Biswas, Bhāgavata Purāna. A Linguistic Study, Particularly from the Vedic Background. Dibrugarh 1968.

Jules Bloch, Le précatif sanskrit. MSL 23 (1927) 120-122. (= Recueil d'articles de Jules Bloch. Textes rassemblés par C. Caillat. [PICI 52]. Paris 1985, p. 148-150).

Id., Les inscriptions d'Asoka. Traduites et commentées. Paris: Les Belles Lettres, 1950.

Otto Böhtlingk, Zur Kritik und Erklärung verschiedener indischer Werke. Bulletin de l'Académie Impériale des Sciences de St.-Pétersbourg 21 (1876) 93-132, 200-242 \& 370-409. (= Mélanges asiatiques tirés du Bulletin de l'Académie Impériale 7 [1876] 448-504, 527-589 \& 615-672).

Id., Bemerkungen zu Manu's Gesetzbuch. Berichte über die Verhandlungen der Königlich Sächsischen Gesellschaft der Wissenschaften zu Leipzig, Philologisch-Historische Classe 48 (1896) 245-250.

Id., Bemerkungen zu einigen Upanishaden. Berichte über die Verhandlungen der Königlich Sächsischen Gesellschaft der Wissenschaften zu Leipzig, Philologisch-Historische Classe 49 (1897) 78-100.

Willem Boudewijn Bollée. Șadviṃśa-Brāhmana. Introduction, Translation, Extracts from the Commentary and Notes. Utrecht: A. Storm, 1956.

Thomas Burrow, The Sanskrit Precative. In: Asiatica. Festschrift Friedrich Weller. Zum 65. Geburtstag gewidmet von sei- 
Caillat 1991

Caillat 1992

Caland 1895

Caland 1896

Caland 1902

Caland 1903

Caland 1912

Caland 1924

Caland 1990

Caland - Henry 1906

$C P D \mathrm{I}$

van Daalen 1980

Delbrück 1888

Delbrück 1897 nen Freunden, Kollegen und Schülern, hrsg. von J. Schubert - U. Schneider. Leipzig: Harrassowitz, 1954, p. 35-42.

Colette Caillat, Asoka et les gens de la brousse (XIII M-N): "qu'ils se repentent et cessent de tuer". BEI 9 (1991) 9-13.

Id., The "Double Optative Suffix" in Prakrit Asoka XIII (N) na hamnesu na ham̃̃eyasu. ABORI 42-43 (1991-1992) 637645 .

Willem Caland, Der Gautamaçrāddhakalpa. Ein Beitrag zur Geschichte und Literatur der Sāmavedaschulen. Bijdragen tot de taal-, land-en volkenkunde van Nederlandse Indie, 6e volgreeks, 1 (1895) 97-112 (= 1990: 7-22).

Id., Die altindischen Todten- und Bestattungsgebräuche mit Benutzung handschriftlicher Quellen dargestellt. [Verhandelingen der Koninklijke Akademie van Wetenschappen, Afd. Letterkunde I/6]. Amsterdam: J. Müller, 1896.

Id., [Besprechung von] Das Mānavaçrautasūtra, hrsg. von F. Knauer. Buch I-II. Göttingische Gelehrte Anzeigen 1902/2, p. 122-127 (= 1990: 602-607).

Id., Über das rituelle Sūtra des Baudhāyana. [AKM XII/1]. Leipzig 1903.

Id., Kritisch-exegetische Bemerkungen zu den Brāhmanas: 1. Zum Śatapathabrāhmana. 2. Zum Kāṭhaka. WZKM 26 (1912) 107-126 (= 1990: 195-214).

Id., Das Śrautasūtra des Āpastamba. Bd. 2. [Verhandelingen der Koninklijke Nederlandse Akademie van Wetenschappen, Afd. Letterkunde, N.R. XXIV/2]. Amsterdam: Koninklijke Akademie van Wetenschappen, 1924.

Id., Kleine Schriften, hrsg. von M. Witzel. [Glasenapp-Stiftung Bd. 27]. Stuttgart: Franz Steiner, 1990.

Id. - Victor Henry, L'Agnistoma. Description complète de la forme normale du sacrifice de soma dans le culte védique. T. 1. Paris: Leroux, 1906.

A Critical Pāli Dictionary, begun by V. Trenckner; revised, continued and ed. by Dines Andersen, Helmer Smith, and Hans Hendriksen. Vol. I. Copenhagen: Ejnar Munksgaard, 1924-1948.

Leendert A. van Daalen, Vālm̄̄ki's Sanskrit. [Orientalia RhenoTraiectina XXV]. Leiden: Brill, 1980.

Berthold Delbrück, Altindische Syntax. [Syntaktische Forschungen V]. Halle an der Saale: Verlag der Buchhandlung des Waisenhauses, 1888.

Id., Vergleichende Syntax der indogermanischen Sprachen. Zweiter Theil. [Grundriss der vergleichenden Grammatik der indogermanischen Sprachen 4]. Strassburg: Trübner, 1897. 
Deussen 1897

Dresden 1941

Edgerton 1952

Eggeling I-V

EWAia I-III

Falk 1994

Geldner 1896

Gonda 1977

Gotō 1980

Gotō 1987

Gotō 1991

Gotō 1997

Griffiths 2004
Paul Deussen, Sechzig Upanishad's des Veda, aus dem Sanskrit übersetzt und mit Einleitungen und Anmerkungen versehen. Leipzig: Brockhaus, 1897.

Mark Jan Dresden, Mānavagṛyasūtra. A Vedic Manual of Domestic Rites. Translation, Commentary and Preface. Groningen: Wolters, 1941.

Franklin Edgerton, Review of Bloch 1950. JAOS 72 (1952) 114-117.

Julius Eggeling, The Śatapatha-Brāhmana According to the Text of the Mādhyandina School. Part I (1882): Books I and II. [SBE 12]; Part II (1885): Books III and IV. [SBE 26]; Part III (1894): Books V, VI, VII. [SBE 41]; Part IV (1897): Books VIII, IX and X. [SBE 43]; Part V (1900): Books XI, XII, XIII and XIV. [SBE 44]. Oxford: Clarendon Press, 1882-1900.

Manfred Mayrhofer, Etymologisches Wörterbuch des Altindoarischen. Bd. I-III. Heidelberg: Winter, 1986-2001.

Harry Falk, Von Götterfiguren und menschlichen Göttern. In: Festschrift Klaus Bruhn zur Vollendung des 65. Lebensjahres, hrsg. von N. Balbir - J.K. Bautze. Reinbek: Wezler, 1994, p. 313-331.

Karl Friedrich Geldner, Awestalitteratur. In: Grundriss der iranischen Philologie. Bd. II, hrsg. von W. Geiger - E. Kuhn. Strassburg: Trübner, 1896-1904, p. 1-53.

Jan Gonda, The Ritual Sütras. [A History of Indian Literature I/2]. Wiesbaden: Harrassowitz, 1977.

Toshifumi Gotō, Ai. utsangá- und Verwandtes. MSS 39 (1980) 11-36.

Id., Die "I. Präsensklasse" im Vedischen. Untersuchung der vollstufigen thematischen Wurzelpräsentia. [SbÖAW $489=$ Veröffentlichungen der Kommission für Sprachen und Kulturen Südasiens 18]. Wien: Verlag der Österreichischen Akademie der Wissenschaften, 1987.

Id., Materialien zu einer Liste altindischer Verbalformen: 4. $\operatorname{dogh} / d u g h / d o h / d u h, 5 . s a v / s u, 6 .{ }^{1} \operatorname{sav}^{i} / s \bar{u}, 7 .{ }^{2}\left(s a v^{i} /\right) s \bar{u}$. Bulletin of the National Museum of Ethnology (Osaka) 16/3 (1991) 681-707.

Id., Materialien zu einer Liste altindischer Verbalformen: 16. chad, 17. chand/chad, 18. chard/chrd, 19. dagh/dhag, 20. dves/ dvis, 21. bandh/badh, 22. ${ }^{1} \operatorname{man}, 23 .{ }^{2} \operatorname{man}, 24 . m n \bar{a}, 25 .{ }^{1}$ yav/yu, 26. ${ }^{2}$ yav $/ y u, 27 . \operatorname{san}^{i}, 28$. star/str, 29. stari/stṛ. Bulletin of the National Museum of Ethnology (Osaka) 22/4 (1997) 1001-1059.

Arlo Griffiths, Paippalāda Mantras in the Kauśikasūtra. In: The Vedas. Texts, Language and Ritual. Proceedings of the Third International Vedic Workshop, Leiden 2002. [Groningen Oriental Studies XX], ed. A. Griffiths - J.E.M. Houben. Groningen: Egbert Forsten, 2004, p. 49-99. 
Hertel 1912

Hoffmann 1955

Hoffmann 1967

Hoffmann 1970

Hoffmann 1976

Hoffmann 1985

Hoffmann 1992

Holtzmann 1884

Hultzsch 1925

Insler 1975

Keith 1908

Kellens 1984

Kern 1868

Kern 1913

KEWA I-IV

Kulikov 1998

Kulikov 2001

Kulikov 2005
Johannes Hertel, The Panchatantra-Text of Purnabhadra. Critical Introduction and List of Variants. [HOS 12]. Cambridge, Mass.: Harvard University Press, 1912.

Karl Hoffmann, Vedisch gámati. MSS 7 (1955) 89-92 (= 1976: 384-386).

Id., Der vedische Prekativtyp yeșam, jeșma. MSS 20 (1967) 25-37 (= 1976: 465-474).

Id., Die Weltentstehung nach dem Jaiminīya-Brāhmaṇa. MSS 27 (1970) 59-67 (= 1976: 516-522).

Id., Aufsätze zur Indoiranistik, hrsg. von J. Narten. Bd. 2. Wiesbaden: Reichert, 1976.

Id., Vedisch kșan. In: Sprachwissenschaftliche Forschungen. Festschrift Johann Knobloch, hrsg. von H.M. Ölberg et al. Innsbruck: Institut für Sprachwissenschaft der Universität, 1985, p. 171-177 (= 1992: 812-818).

Id., Aufsätze zur Indoiranistik. Bd. 3, hrsg. von S. Glauch - R. Plath - S. Ziegler. Wiesbaden: Reichert, 1992.

Adolf Holtzmann, Grammatisches aus dem Mahabharata. Ein Anhang zu William Dwight Whitney's Indischer Grammatik. [Bibliothek indogermanischer Grammatiken II, Anhang I]. Leipzig: Breitkopf and Härtel, 1884.

Eugen Hultzsch, Inscriptions of Asoka. New edition. [Corpus Inscriptionum Indicarum 1]. Oxford: Clarendon Press, 1925.

Stanley Insler, The Vedic type dheyām. Die Sprache 21/1 (1975) 1-22.

Arthur B. Keith, The Śāikhāyana Āranyaka. With an Appendix on the Mahāvrata. London: Royal Asiatic Society, 1908.

Jean Kellens, Le verbe avestique. Wiesbaden: Reichert, 1984.

Hendrik Kern, Die Yogayâtrâ des Varâhamihira. Indische Studien 10 (1868) 161-212 (= 1913: 97-168).

Id., Verspreide Geschriften. I. 's Gravenhage: Nijhoff, 1913.

Manfred Mayrhofer, Kurzgefaßtes etymologisches Wörterbuch des Altindischen. Bd. I-IV. Heidelberg: Winter, 1951-1980.

Leonid I. Kulikov, Vedic -ya-Presents: Semantics and the Place of Stress. In: Sprache und Kultur der Indogermanen. Akten der X. Fachtagung der Indogermanischen Gesellschaft, hrsg. von W. Meid. Innsbruck: Institut für Sprachwissenschaft der Universität, 1998, p. 341-350.

Id., The Vedic-ya-Presents. Diss. Leiden University 2001.

Id., Length Vacillation - $\bar{\imath} y$-//-iy- and Related Phenomena in Vedic. In: Sprachkontakt und Sprachwandel. Akten der XI. Fachtagung der Indogermanischen Gesellschaft, hrsg. von G. Meiser - O. Hackstein. Wiesbaden: Reichert, 2005, p. 295-317. 
Kulkarni 1943

Kümmel 1996

Leumann 1968

Minard 1956

Modak 1993

Monier-Williams

Morgenroth 1981

Narten 1964

Narten 1982

Narten 1995

Oberlies 2000

Oberlies 2003

Oertel 1895

Oertel 1926

Oertel 1927

Oertel 1994
Eknath D. Kulkarni, Unpāninian Forms and Usages in the Critical Edition of the Mahābhārata. 2. Participles. BDCRI 4 (1942-1943) 227-245.

Martin Kümmel, Stativ und Passivaorist im Indoiranischen. [HS-Ergänzungsheft 39]. Göttingen: Vandenhoeck \& Ruprecht, 1996.

Manu Leumann, Zu den lautlichen Fernwirkungen im Altindischen. In: Pratidānam. Indian, Iranian, and Indo-European Studies Presented to F.B.J. Kuiper on his Sixtieth Birthday. [Janua linguarum, Series Maior 34], ed. J.C. Heesterman et al. The Hague: Mouton, 1968, p. 53-59.

Armand Minard, Trois énigmes sur les cent chemins. Recherches sur le Śatapatha-Brāhmaṇa. Tome II. [PICI 3]. Paris: E. de Boccard, 1956.

B.R. Modak, The Ancillary Literature of the Atharva-Veda. A Study with Special Reference to the Pariśiștas. New Delhi: Rashtriya Veda Vidya Pratishthan, 1993.

Monier Monier-Williams, A Sanskrit-English Dictionary. Oxford: Clarendon Press, 1899.

Wolfgang Morgenroth, Glossen in der Chāndogya-Upanishad. IndT 8-9 (1980-1981 [Dr. Ludwik Sternbach Commemoration Volume]) 283-291.

Johanna Narten, Die sigmatischen Aoriste im Veda. Wiesbaden: Harrassowitz, 1964.

Id., Zu einem Optativ im Śatapathabrāhmaṇa. MSS 41 (1982) 127-137 (= 1995: 254-262).

Id., Kleine Schriften I. Hrsg. von M. Albino - M. Fritz. Wiesbaden: Reichert, 1995.

Thomas Oberlies, Pāli. A Grammar of the Language of the Theravāda Tipitaka. [Indian Philology and South Asian Studies 3]. Berlin - New York: de Gruyter, 2000.

Id., A Grammar of Epic Sanskrit. [Indian Philology and South Asian Studies 5]. Berlin - New York: de Gruyter, 2003.

Hanns Oertel, Emendations to the Jāiminīya-Upaniṣad-Brāhmaṇa, sent in part by [O.] Böhtlingk and in part by [R.] Roth. JAOS 16 (1894-1896) cexlii-cexliii (= 1994: I/26f.).

Id., The Syntax of Cases in the Narrative and Descriptive Prose of the Brāhmanas. I. The Disjunct Use of Cases. [Indogermanische Bibliothek. I. Reihe: Grammatiken 18]. Heidelberg: Winter, 1926.

Id., Besprechung von ŚBK, ed. Caland. ZII 5 (1927) 98-123 (= 1994: I/557-582).

Id., Kleine Schriften. Teil I-II, hrsg. von H. Hettrich - Th. Oberlies. [Glasenapp-Stiftung 32]. Stuttgart: Steiner, 1994. 
Olivelle 1992

Olivelle 1998

Olivelle 2000

Patyal 1973

$P W$ I-VII

Renou 1940

Renou 1947

Renou 1957

Salomon 1981

Schneider 1978

Sen 1949

Sen 1964

Sil 1961

Smith 1951

Sternbach 1956

Tedesco 1953

Tichy 1993

Tsuji 1957
Patrick Olivelle, Samnyāsa Upanișads. Hindu Scriptures on Asceticism and Renunciation. Translated with Introduction and Notes. New York - Oxford: Oxford University Press, 1992.

Id., The Early Upanișads. Annotated Text and Translation. Ibid. 1998.

Id., Dharmasūtras. The Law Codes of Āpastamba, Gautama, Baudhāyana and Vasiștha. Annotated Text and Translation. Ibid. 2000.

Hukam Chand Patyal, Some Remarkable Verbal Forms of the Gopatha Brāhmaṇa. BDCRI 33 (1973) 253-258.

Otto Böhtlingk - Rudolph Roth, Sanskrit-Wörterbuch. St. Petersburg: Buchdruckerei der Kaiserlichen Akademie der Wissenschaften, 1855-1875.

Louis Renou, Sur certaines anomalies de l'optatif sanskrit. BSL 41 (1940) 5-17.

Id., Les écoles védiques et la formation du Veda. [Cahiers de la Sociéte Asiatique 9]. Paris: Imprimerie nationale, 1947.

Id., Remarkable Words from Bāṣkala, Chāgaleya, Ārṣeya and Śaunaka Upanishads. Vāk 5 (1957) 125-131.

Richard Salomon, A Linguistic Analysis of the Mundaka Upanișad. WZKS 25 (1981) 91-105.

Ulrich Schneider, Die grossen Felsen-Edikte Aśokas. Kritische Ausgabe, Übersetzung und Analyse der Texte. [Freiburger Beiträge zur Indologie 11]. Wiesbaden: Harrassowitz, 1978.

Nilmadhav Sen, The Secondary Conjugations in the Rāmāyaṇa. Poona Orientalist 14 (1949) 89-106.

Id., The Influence of Middle Indo-Aryan on the Language of the Rāmāyaṇa. Indian Linguistics 25 (1964) 200-201.

Harendra Chandra Sil, A Study of the Un-Pāninian VerbForms in the Critical Edition of the Ādiparvan of the Mahābhārata. The Indian Historical Quarterly 37 (1961) 38-47.

Helmer Smith, Retractationes rhythmicae. [Studia Orientalia XVI] 5]. Helsinki: Societas Orientalis Fennica, 1951.

Ludwik Sternbach, Cānakya's Aphorisms in the Hitopadeśa (I). JAOS 76 (1956) 115-130.

Paul Tedesco, Sanskrit a-mred 'to repeat'. JAOS 73 (1953) 77 85.

Eva Tichy, Kollektiva, Genus femininum und relative Chronologie im Indogermanischen. HS 106/1 (1993) 1-19.

Naoshirō Tsuji, Linguistic Features of "Four Unpublished Upanișadic Texts". In: Felicitation Volume Presented to Professor Sripad Krishna Belvalkar, ed. S. Radhakrishnan et al. Banaras: Motilal Banarasi Dass, 1957, p. 19-27. 
Uhlenbeck 1899

Varenne 1971

VWC-Sa./Br./Up./Sū. Vishva Bandhu (general ed.), A Vedic Word-Concordance. Vol. I: Samhitās. 6 parts - Vol. II: The Brāhmanas and the Áranyakas. 2 parts - Vol. III: Upanișads. 2 parts - Vol. IV: Vedānga-sūtras. 4 pts. Lahore/Hoshiarpur: Vishveshvaranand Vedic Research Institute, 1935-1965 ( $\left.{ }^{2} 1973-1992\right)$.

Weber 1865

Werba 1997

Whitney 1884

Whitney 1885

Whitney 1971

Christiaan Cornelis Uhlenbeck, Etymologisches Wörterbuch der altindischen Sprache. Amsterdam: J. Müller, 1899.

Jean Varenne, Upanishads du Yoga. Traduites du sanskrit et annotées. Paris: Gallimard, 1971.

Albrecht Weber, Analyse der in Anquetil du Perron's Uebersetzung enthaltenen Upanishad [Fortsetzung und Schluß]. Indische Studien 9 (1865) 1-173.

Chlodwig H. Werba, Verba IndoArica. Die primären und sekundären Wurzeln der Sanskrit-Sprache. Pars I: Radices Primariae. Wien: Verlag der Österreichischen Akademie der Wissenschaften, 1997.

William Dwight Whitney, The Study of Hindu Grammar and the Study of Sanskrit. AJPh 5/3 (1884) 279-297 (= 1971: 287$305)$.

Id., The Roots, Verb-Forms, and Primary Derivatives of the Sanskrit Language. Leipzig: Breitkopf and Härtel, 1885.

Whitney on Language. Selected Writings of W.D. Whitney. Cambridge, Mass.: MIT Press, 1971. 